BNL 51224 Vol. I

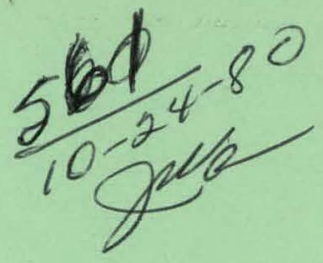

\title{
ECONOMIC IMPACT OF USING NONMETALLIC MATERIALS IN LOW TO INTERMEDIATE TEMPERATURE GEOTHERMAL WELL CONSTRUCTION
} VOLUME I

December 1979

\section{MASTER}

Prepared by the

NATIONAL WATER WELL ASSOCIATION

WORTHINGTON, OHIO

For the

PROCESS SCIENCES DIVISION

DEPARTMENT OF ENERGY AND ENVIRONMENI

BROOKHAVEN NATIONAL LABORATORY UPTON, NEW YORK 11973 


\section{DISCLAIMER}

This report was prepared as an account of work sponsored by an agency of the United States Government. Neither the United States Government nor any agency Thereof, nor any of their employees, makes any warranty, express or implied, or assumes any legal liability or responsibility for the accuracy, completeness, or usefulness of any information, apparatus, product, or process disclosed, or represents that its use would not infringe privately owned rights. Reference herein to any specific commercial product, process, or service by trade name, trademark, manufacturer, or otherwise does not necessarily constitute or imply its endorsement, recommendation, or favoring by the United States Government or any agency thereof. The views and opinions of authors expressed herein do not necessarily state or reflect those of the United States Government or any agency thereof. 


\section{DISCLAIMER}

Portions of this document may be illegible in electronic image products. Images are produced from the best available original document. 
BNL 51224 Vol. I

UC-66d

(Geothermal Energy-Utilization

Technology - TID-4500)

\title{
ECONOMIC IMPACT OF USING NONMETALLIC MATERIALS \\ IN LOW TO INTERMEDIATE TEMPERATURE GEOTHERMAL WELL CONSTRUCTION
}

\author{
VOLUME I
}

\author{
December 1979 \\ Prepared by the

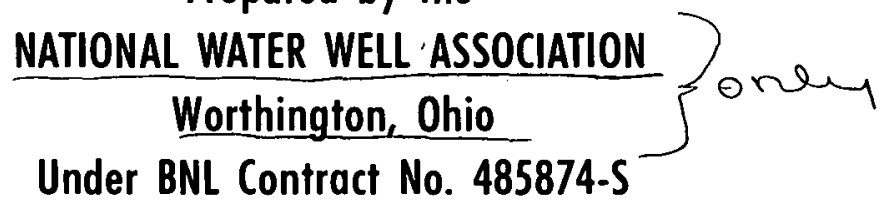

Contributors:

Tylor E. Gass

Woyne H. Purdin

Dana M. Armitage

For the

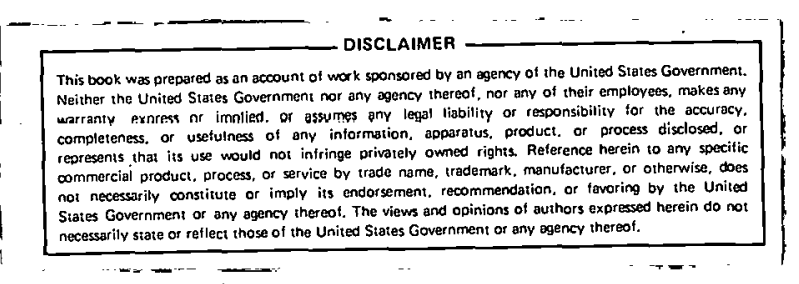

PROCESS SCIENCES DIVISION

DEPARTMENT OF ENERGY AND ENVIRONMENT

BROOKHAVEN NATIONAL LABORATORY

ASSOCIATED UNIVERSITIES, INC.

UNDER CONTRACT NO. DE-AC02-76CH00016 WITH THE

UNITED STATES DEPARTMENT OF. ENERGY 


\section{DIŚCLAIMER}

This book was prepared as an account of work sponsored by an agency of the United States Government. Neither the United States Government nor any agency thereof, nor any of their employees, makes any warranty, express or implied, or assumes any legal liability or responsibility for the accuracy, completeness, or usefulness of any information, apparatus, product, or process disclosed, or represents that its use would not infringe prlvately owned righte. Reference herein to any speclfic commerclal product, process, or service by trade name, trademark, manufacturer, or otherwise, does not necessarily constitute or imply its endorsement, recommendation, or favoring by the United States Government or any agency thereof. The views and opinions of authors expressed herein do not necessarily state or reflect those of the United States Government or any agency thereof.

Printed in the United States of America Available from

National Technical Information Service

U.S. Department of Commerce

5285 Port Royal Road Springfield, VA 22161

Price: Printed Copy $\$ 5.25$; Microfiche $\$ 3.00$ 


\section{TABLE OF CONTENTS}

Page

Acknowl edgement

iv

Foreword

v

Executive Summary

vi

Introduction

1

Description of the Analysis

Results and Discussion

22

Notes On Units

50

References

51 


\section{ACKNOWLEDGEMENTS}

This report is an accumulation of efforts by many people starting with Dr. Robert R. Reeber, program manager for the Geochemical Engineering and Materials Program of the Department of Energy Division of Geothermal Energy. Lawrence E. Kukacka of the Brookhaven National Laboratory Geothermal Materials Group acted as liaison between Brookhaven National Laboratory and the National Water Well Association. As principal investigator, Tyler E. Gass coordinated and supervised the project work and also acted as liaison with Brookhaven. Dr. Jay H. Lehr, Wayne H. Purdin, Dana M. Armitage, John Massey-Norton, and Mrchael Eberle participaled in dat collection and rcport writing. nssisting in data rollection and report review wás an advisory committee composed of manufacturers of metali ic and nonmetallic casing and scientists who have researched well casing design criteria and geothermal system economics. The efforts of Madelyn Pêroni who edited and re-edited most of the report are al so acknowledged with appreciation.

Members of the advisory committee are as follows:

Stan Mruk, Plastic Pipe Institute

Dave Anderson, Geothermal Resources Council

Gene Culver, Geo-Heat Ut ilization Center

Lyman E. Lorensen, Lawrence Livermore Lab.

Huseyin Ozbek, Lawrence Berkeley Lab.

John A. Peterson, ARMCO, Inc.

Stephen A. Finnegan, Naval Weapons Center

E. G. DiBello, EG \& G Idaho, Inc.

Carl E. Kurt, Auburn University

Stephen D. Cramer, Rureau of Mines Metal lurgical Research Center.

Richard Deitch, Battelle's Columbus Laboratories 
FOREWORD

The Process Science Division of the Department of Energy and Environment at Brookhaven National Laboratory has a leading role in the development of safe, reliable, and economical nonmetallic materials for geothermal applications. As part of this effort, the National Water Well Association was awarded a contract to assess the cost-effectiveness and economic impact of using nonmetallic materials in the construction of production and injection wells for various low to imtermediate temperature applications. However, results of this study may be useful in evaluating the economics of using nonmetallic materials in wells designed for mining, subsurface investigations, thermal storage, coal gasification, oil and gas production, brine production, waste disposal, and water supply.

Background information on direct use of geothermal energy, hydrogeology, well design, and materials performance as well as specific economic data provided the basis for cost comparisons and estimates of savings resulting from the use of nonmetallic materials. 


\section{EXECUTIVE SUMMARY}

This report presents the results of an exhaustive literature search and evaluation concerning the properties and economics of commercially available nonmetallic well casing and screens. These materials were studied in terms of their use in low to intermediate temperature geothermal well construction.

It has been reported that the cost of production and injection wells for geothermal direct-use systems accounts for 50 to 80 percent of the tot.al cost. 17 Direct use of low to intermediate temperature geothermal resources for industrial, commercial, residential, agriculturàl, and recreationd purpuses will expand duc to the rising. cost of conventional fuels and the incentive of geothermal tax credils for homeowners, corporations, and ut $111 t$ tes.

Given current estimates of future direct use of geothermal energy between the years 1981 and 2013, potential annual savings of 116 to 442 million dollars could result from the use of nonmetali ic materials in geothermal wells. This positive economic impact is based upon the following assumptions:

1. Drilling costs are averaged for each region

2. Casing and screen costs are based on manufacturers' list prices

3. No major maintenance will be required during the service lives of nonmetallic wells

4. The cost of Illajor maintenance for metallic weilis is equal to approximately 10 percent of the total current replacement cost

5. Service life is the same for both nonmetallic and metallic wells

6. Inflation rate is 12 percent, compounded yearly

7. Interest rate on burruwed muiney is 15 percent, compounded yearly

8. Annual savings are based on the number of wells installed between 1981 and 2013 and on all expenditures incurred in maintaining these wells during their service lives

The advantages of nonmetallic well casing compared to metallic well casing include: lighter weight, greater abrasion resistance, smoother walls, greater chemical resistance, higher strength-to-weight ratios, greater resiliency and flexibility, no contamination problems due to the introduction of corrosion products into process streams, 
and lower initial cost in some cases. Due to the lighter weight of plastic casing, the energy required to manufacture a length of plastic casing is about one-fourth that required to produce an equivalent length of steel casing.

Disadvantages of nonmetallic casing used in geothermal wells are: low thermal conduct ivity, low impact strength, decreased st iffness and structural strength at high temperatures, and high coefficients of thermal expansion.

The annual cost of low temperature geothermal wells constructed of nonmetallic materials is less than that of steel wells. This is true for all types of nonmetallic materials suitable for specific geothermal systems in various regions of the United States.

Most of the nonmetallic materials investigated in this report can be divided into two groups on the basis of annual savings when compared with steel wells. These groups and their members are listed in order of decreasing savings: Group 1 - styrene butadiene rubber, asbestos cement, PVC, and ABS; Group 2 - reinforced plast ic mortar, fiberglass reinforced vinylester, laminated wood, fiberglass reinforced epoxy, and CPVC.

Polymer concrete does not fit into either group. It results in the least savings for shallow wells using temperatures less than $82^{\circ} \mathrm{C}\left(180^{\circ} \mathrm{F}\right)$ and. for well fields with a large number of deep wells using temperatures less than $121^{\circ} \mathrm{C}\left(250^{\circ} \mathrm{F}\right)$. For most other situations, polymer concrete results in the highest annual savings.

The materials in group 1 are limited to shallow $(<305 \mathrm{~m})$, $(<1000 \mathrm{ft})$ and relatively low-temperature $\left(\left\langle 83^{\circ} \mathrm{C}\right),\left(\left\langle 180^{\circ} \mathrm{F}\right)\right.\right.$ wells. Of the materials in group 2, fiberglass reinforced epoxy is the best material in terms of stiffness and strength, heat resistance, chemical resistance, ease of installation, and availability.

Based on the results of this study, the following recommendations are proposed:

1. The potential recoverable thermal energy from shallow ground-water reservoirs of ambient temperature should be estimated. Such an estimate should consider limitations of well depth, water temperature, flow rate and quality, and design constraints of ground-water geothermal 
heat pumps. The NWWA has al ready published a detailed map showing shallow ground water temperatures in the contiguous United States.

2. There is a great need for more precise, controlled experiments involving both metallic and nonmetallic materials exposed to various natural and simulated geothermal environments. These experiments will determine the various damage mechanisms and identify those that are the most significant in each case by quantifying corrosion rates of metals and loss of strength of nonmetals.

3. An international survey of the use of nometallic casing in low to intermediate temperature geothermal wells should be undertaken. The survey would obtain information on the type of casing used; size, depth, and temperature of well; length of service; and problems and other comments concerning actual field experience.

4. The economics of using nometallic casing for geothermal weills should be examined in more deldil using site specific data as input for a computer-based model.

5. The economic feasibility of using nummetallic casing for nongeothermal, energy-related applications (such as uranium leach mining, thermal storage of waste heat, and coal gasification) should be examined.

6. Research should be conducted on the feasibility of fabricating well casing from polypropyl ene. The low specific gravity, high heat resistance, low water absorption, good chemical resistance, plus low cost of polypropyleme make it an idcal material for genthermal well casing.

7. For geothermal wells with water temperatures between $66^{\circ}-150^{\circ} \mathrm{C}\left(150^{\circ}-302^{\circ} \mathrm{F}\right)$ and depths less than $2000 \mathrm{~m}(6562$

$\mathrm{ft}$ ), fiberglass reinforced epoxy casing and screen should be used. For geothermal wells less than $66^{\circ} \mathrm{C}\left(150^{\circ} \mathrm{F}\right)$ and $305 \mathrm{~m}$ (1000 ft), PVC should be used or ABS depending upon its availability. 
CHAPTER 1. INTRODUCTION

While the world's supply of fossil fuels rapidly diminishes, the cost of these supplies steadily increases. of more immediate concern is our nation's dependence on foreign oil which places us in an economically weak position when dealing with oil exporting nations and may result in sudden oil shortages and/or price increases. Given this predicament, our nation is compelled to search for additional energy sources.

The development of geothermal resources has become a vital facet of this search. However, due to the severity of geothermal environments, scaling and corrosion problems in well casings and screens present major obstacles to harnessing this form of energy 1. To avoid this problem, wells can be constructed of low alloy steel casing and screen, which adds significantly to the cost of the well. Fortunately, a number of nonmetallic materials will, under certain conditions, provide the same protective characteristics of low alloy steel, but at a much lower cost. The use of nonmetallic materials could prove to be cost-effective even when corrosion and scaling are not problems.

While geothermal reservoir temperatures can be quite high, this study focuses on the more widespread lowtemperature $\left(<90^{\circ} \mathrm{C}\right),\left(<194^{\circ} \mathrm{F}\right)$ and intermediate-temperature $\left(90^{\circ}\right.$ to $\left.150^{\circ} \mathrm{C}\right),\left(194^{\circ}\right.$ to $\left.302^{\circ} \mathrm{F}\right)$ reservoirs'. To avoid repetition throughout this report, these two will be referred to as one $10 \mathrm{w}$-temperature $\left(<150^{\circ} \mathrm{C}\right)\left(<302^{\circ} \mathrm{F}\right)$ range. Most geothermal sources have temperatures below $150^{\circ} \mathrm{C}$ $\left(302^{\circ} \mathrm{F}\right)$, which is the current threshold temperature for economic electric power generation. 2 of the ident ified natural heat sources in the western United States, approximately 85 percent have base tempcratures less than $150^{\circ} \mathrm{C}\left(302^{\circ} \mathrm{F}\right)$. In the eastern United States, there appear to be many low-temperature sources. Some space heating systems can use geothermal sources with temperatures as low as $38^{\circ} \mathrm{C}\left(100^{\circ} \mathrm{F}\right)$. With the use of the ground water geothermal heat pump, ground water with temperatures as 1 ow as $4^{\circ} \mathrm{C}$ $\left(39^{\circ} \mathrm{F}\right)$ can be used as a heat source for many applications. Thus, the availability and wide applicability of low-temperature geothermal resources compensate for their relatively low energy content.

This report is divided into two volumes. Volume one contains the executive summary;" introduction, description of 
analysis, and discussion of results. Volume two contains appendices which provide detailed information on direct use of geothermal energy, hydrogeologic factors affecting the design and construction of low-temperature geothermal wells, properties of metallic and nonmetallic materials, and special considerations in the design and construction of low-temperature geothermal wells using nonmetallic materials.

Within the last seven years, a considerable amount of research has been done on the performance and economics of various materials in geothermal and nongeothermal environments. The results of some of the more important. studies are summarized below.

\section{CORROSION AND SCALING IN GEOTHERMAL ENVIRONMENTS}

The Radian Corporation cumpiled a manual of materials-selection guidelines for geothermal power systems 3 . This is the most up-to-date and comprehensive collection of test data concerning metallic and nonmetallic construction materials for power production from liquid-dominated, U.S. geothermal rešources. This manual contains data on corrosion rates from materials-performance tests using fluids from five known geothermal resource areas. General guidelines are presented for the use of various materials under different conditions in geothermal puwer systems.

Brookhaven National Laboratory is investigating alternate construction materials for geothermal applications 4 . The development of a system composed of styrene, acrylonitrile, and acrylamide ur methacrylanide and 70-30 sand to portland cement is emphasized since it forms a high-strength, thermally and chemically stable polymer concrete for use in geothermal environments. Results of lahoratory and field tests indicated that the materials can be used for casing or protect ive limers on casing in rlowing brine containing $26,000 \mathrm{ppm}$ salt at $240^{\circ} \mathrm{C}\left(464^{\circ} \mathrm{F}\right)$ with little or no corrosion or scaling.

I.. awrence Livermore Laboratory investigated the performance of polymeric and composite materials in hotflowing geothermal brine. The most recent study 5 employed several levels of temperature $\left(60^{\circ}\right.$ to $\left.190^{\circ} \mathrm{C}\right)$, $\left(140^{\circ}\right.$ to $374^{\circ} \mathrm{F}$ ) flow conditions, and duration of exposure. Fluorocarbon and hydrocarbon polymers had the least scale, 
polyesters and polysulfide had a moderate amount of scale, and reinforced polymers had the most scale. Surface roughness appeared to be an important factor in promoting scaling and scale adhesion.

A study of geothermal corrosion was conducted at the Coso Thermal Area, Naval Weapons Center, China Lake, California 6 . Nine different common construction-grade metallic and nonmetallic piping materials were tested for periods up to one year in three distinctive intermediate-temperature environments (acid-sulfate steam, ground water-diluted steam, and hot, mineralized alkaline water) under aerobic and anaerobic conditions. Corrosion results for the three fluid systems were compared, and specific materials were recommended for use in each fluid type. In general, 304 stainless steel was the most

resistant metal while asbestos cement was the most resistant nonmetal. Additional metallic and nonmetallic materials have been tested, but the results will not be available until late 1980.

\section{CORROSION IN BRINE WELLS}

0ilwell Research, Inc. investigated the cause and prevention of corrosion in the casing, well screen, pump, and pump column of salt-water wells \%? A major corrosion preventive measure is the selection of optimum materials for corrosion resistance and long life. D-2 Ni Resist, 304 and 316 stainless steels, asbestos cement, and fiberglass. reinforced pipe have performed well in casing, well screen, and tubing. Plastic lined and cement lined casings have been used with little success due to coating damage when installing the pump.

\section{I. CORROSION IN DESALINATION PLANTS}

The Dow Chemical. Company compiled a Desalination Materials Manual 8 , which presents test results of metallic and nonmetallic materials in sea water at temperatures up to $121^{\circ} \mathrm{C}\left(250^{\circ} \mathrm{F}\right)$. At high temperatures, Bisphenol-A-Epoxy, halogenated vinylester Derakane, glass reinforced epoxy, and polysulfone gave acceptable results. Factors which ensure maximum life of nonmetallic materials and economic factors in materials selection are discussed. 
IV. NONMETALLIC MATERIALS FOR WELL CONSTRUCTION

The American Society for Testing and Materials Task Group on Geothermal Seals held a seminar to stimulate new sealing concepts utilizing available elastomer and other polymer materials, and to produce meaningful ASTM test procedures for geothermal seals 9 . It was concluded that since geothermal conditions are so severe and different from those in other elastomer applications, nearly all previous test data are not applicable. Elastomers for geothermal use must be investigated under the appropriate test conditions of high pressure, reducing atmospheres, and hydrolysis.

The National Water Well Assoclation and the Flastic Pipe Instilule cullaborated in compiling a malual of installation practices for thermoplastic water well casing 10. This manual details salient features of drilling and installation techniques using thermoplastic casing. It reviews the state-of-the-art both on a practical (field-oriented) and theoretical basis. It is designed for a wide audience, including water well drillers, hydrogeologists, engineers, and public officials.

Radian Corporation investigated the use of fiberglass reinforced plastic (FRP) pipe for water well applications. 11 Tests were developed and implemented on commercially available FRP pipe. The results of these tests can be used in designing an optimum well systen. A cost comparison between FRP and metallic casing showed that FRP was more economical than stainless steel and other alloys. Appendices contain information on drlllimy and casing installation, installation of well screen, and well development.

\section{ECONOMICS}

A number of acceptahle methods are available for an economic comparison of alternate materials for corrosion control. The most commoll lielliuds =- singlc payment "Present Worth" or uniform annual series -- "Annual Cost" can be obtained from discounted cash flow analysis. Many researchers 12-14 have used these methods to determine the optimum economical measures for controlling corrosion in various conditions. They emphasized that the economic aspects of solving corrosion problems are more important than metallurgical aspects and corrosion data. 
Dow Chemical, U.S.A. compared the installed cost of corrosion-resistant piping 15. Included in the study are cost ratios and rank-ordering of the installed costs of building both complex and straight-run piping systems based on various materials of construction, labor costs, and construction methods. Various metali ic piping, FRP piping, and lined steel piping were compared. The data are presented in a computer-printed format, which is updated periodically. On an installed cost basis, FRP piping is more cost-effective than carbon steel piping.

The University of Colorado and Environmental Consulting Services, Inc. of Boulder, Colorado, collaborated in a study of the technical and economic feasibility of using lowtemperature geothermal sources in Colorado 16. One of the conclusions of this study was that well depth and diameter is a major economic factor only in small- and medium-size district heating systems involving 100 homes or less. Each well should deliver approximately .25 gpm (.016 l/s) of $65^{\circ} \mathrm{C}$ water to each home, with larger requirements for buildings such as schools and hospitals. Fiberglass reinforced plastic well casing was recommended as an economical substitute for steêl casing. Annual maintenance costs for API/K55 steel wells were estimated at six percent of initial equipment costs.

Gruy Federal, Inc. used a computer model, GEODEC, to calculate geothermal well costs for direct use processes 17. Costs for drilling and casing were est imated from a 1976 study of deep well costs in hard and soft rock formations 18. Annual maintenance and labor costs were estimated as 10 percent of total capital costs. It was concluded that the wells and equipment for producing and reinjecting geothermal fluids are the major contributors to the cost of geothermal energy. 'In half of the processes studied, this amounted to 75 percent. or more of the total cost.

The present study is unique in that it compares the cost-effect iveness of metallic versus nonmetallic materials, and evaluates the economic impact that the use of nonmetallic well construction materials will have on low to intermediate temperature genthermal energy utilization in the United States. 
CHAPTER 2. DESCRIPTION OF ANALYSIS

I. BASIC ASSUMPTIONS

In determining the actual cost of constructing wells so that valid comparisons between alternate materials can be made, the following factors must be considered:

1. Drilling and installation costs in various types of subsurface materials

2. Initial cost of the vell casing and screen

3. Transportation costs of the casing and screen

4. Pumping cost

5. Cost and frequency of well liaintenance

6. Service lives of various materials in fluids of different temperature and cheinistipy

7. Replacement costs of the well casing and screen

8. Anticipated inflation rate

9. Interest rate

10. Investment tax credit, where applicable

11. Cost of shutdowns during maintenance and replacement

12. Salvage value, if any

Once this information is collected, it becomes relatively easy to compare the costs of alternate materials by using a capital recovery factor. This will give the annual cost to repay the initial investment plus interest over the lifetime of the well.

If alternative materials have costs which are equal or nearly equal, these costs can be ignored because only differences need be considered.

Some of the cost factors listed previously have been determined from a recent well cost survey, current manufacturers price lists, and conversations with various experts. Other factors were estimated or given average values.

Whether a cost is known or estimated, it is influenced by certain assumptions. These assumptions and their justification will be discussed in the following paragraphs.

\section{A. Drilling Costs}

l:ell drilling costs using steel casing depend on such factors as required yield, hole diameter, type of geologic 
formation, and well depth. These factors are determined by local conditions and type of geothermal application.

Therefore, the cost comparison will include a series of illustrative examples using typical values for specified applications in various ground-water regions of the United States.

Table 2.1 shows the cost per meter for drilling holes of various diameters in the 10 ground-water regions, the predominant types of aquifers in each region, and the typical ranges of maximum yield and well depth in each aquifer. The costs are average values and no attempt was made to distinguish between costs for drilling in different materials in each region. Considering the variety of formations encountered during drilling and the scope of this study, average costs should be used.

The installation cost depends on the ease of handling, joining method, diameter of casing, length of each casing section, and total footage of casing. Generally, installation cost is not specified but is part of the drilling cost. Thus if less time and fewer workers are needed to install a nonmetallic casing, the drilling cost should be lower than the drilling cost for steel casing in similar types of material.

A comparison of drilling costs for PVC and steel 48 showed that drilling costs were approximately 25 percent less for PVC using 152 to $203 \mathrm{~mm}$ (6-8 in) casing and 58 percent less for larger diameter casing. This is due primarily to fewer workers and secondarily to the faster rate of installation for PVC $(61 \mathrm{~m} / \mathrm{hr})(200 \mathrm{ft} / \mathrm{hr})$. The same amount of time is required to install other thermoplastics and wood, twice as much time is needed for transite and RPM, and half as much for FRP. The drilling cost for transite and RPM should be reduced 22 percent for 152 to $203 \mathrm{~mm}$ (6-8 in) casing and 55 percent for larger casing. For FRP, drilling cost should be reduced 28 percent for 152 to $203 \mathrm{~mm}$ (6-8 in) casing and 61 percent for larger casing. The cost of drilling using polymer concrete should be about equal to that of steel since the same amount of labor and time are required.

\section{B. Casing Custs}

In Appendix $C$ of Volume II, 20 types of materials are examined in terms of their physical properties and chemical 
Table 2.1

Cost of Drilling in Ten Ground Water Regions $(a)(\$ / m)$

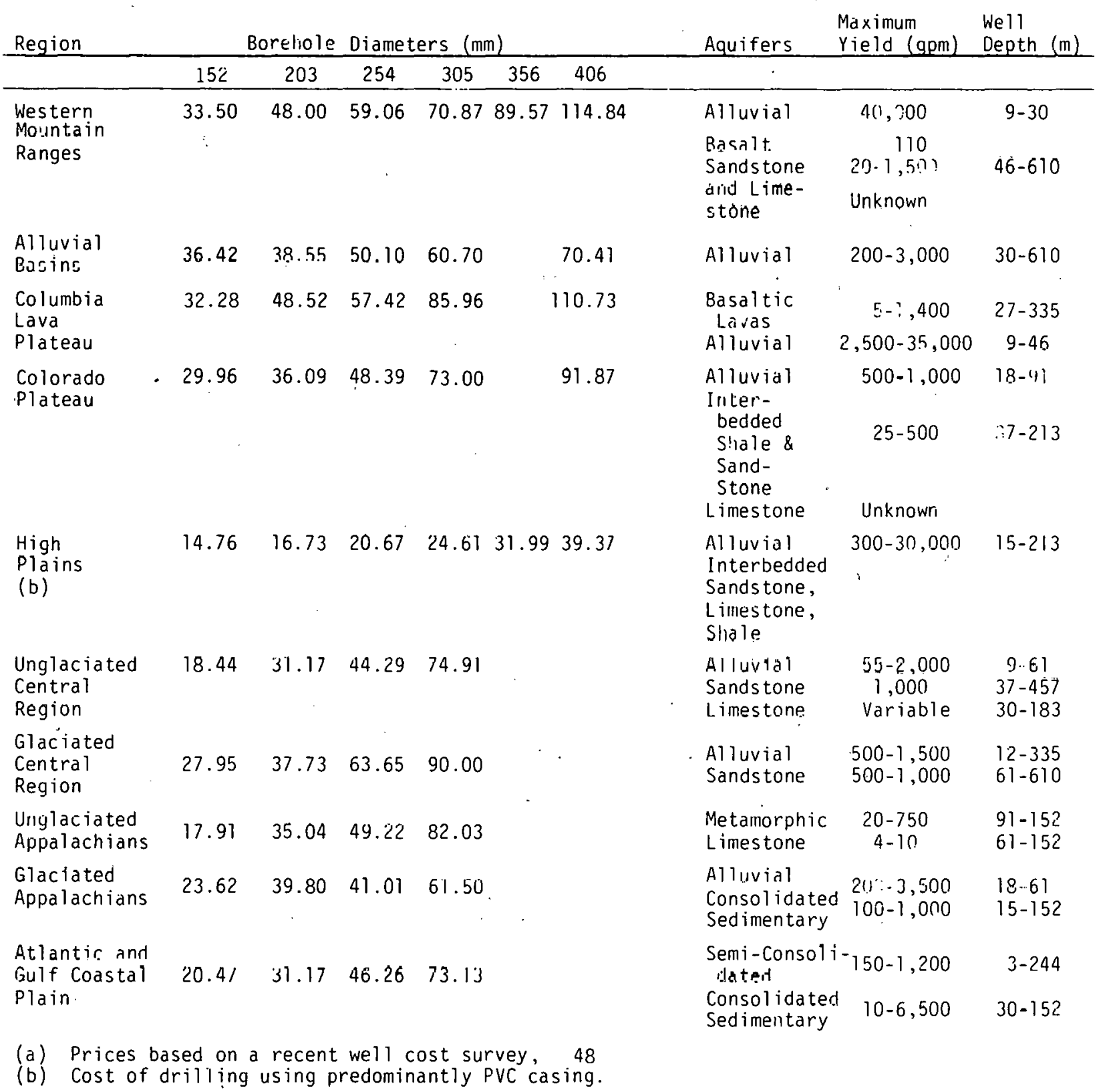


resistance. Of these materials, only PVC, ABS, Transite, fiberglass reinforced epoxy, low carbon steel, Type 304 and 316 stainless steel, Monel 400 , titanium and polymer concrete have been tested under low-temperature geothermal well conditions. Other materials such as CPVC, styrene butadiene rubber, 1 aminated wood, Techite or RPM, and fiberglass reinforced vinylester have been used successfully as water well casing but have not yet been tested under geothermal conditions.

In the cost comparison, only those materials which are used for well casing and screens will be considered, whether or not they have been tested. The results of a survey of water well contractors who use nonmetall ic casing 10 are illustrated in Figure 2.1. Materials not shown were not reported in the survey but their use can be assumed to be less than one percent. Liner materials were not considered as candidate materials for the following reasons: 1) Some liner materials can be easily abraded or shattered during drilling, pump installation, or operation. If a liner is perforated, it no longer protects the steel. 2) Some liner materials have high coefficients of thermal expansion, resulting in separation of the liner from the steel and eventual collapse. 3) The flanged joint, used to couple sections of lined pipe, is not easily adapted to well installations due to its inherent weakness and projecting lip.

Casing and screen costs depend on the diameter, wall thickness, required lengths, and type of joining system used. Diameters considered here range from 152 to $610 \mathrm{~mm}$ (6-24 in), depending on yield. Table 2.2 shows recommended casing sizes for various yields. Most nonmetallic casings have diameters of $406 \mathrm{~mm}$ (16 in) or less. Steel casing is assumed to be standard weight API $5 \mathrm{~L}$ Grade $A$ line pipe with plain ends. For more aggressive environments, API Gradc K-55 seamless casing is used. Steel screens are either galvanized low-carbon steel or 304 stainless steel. 


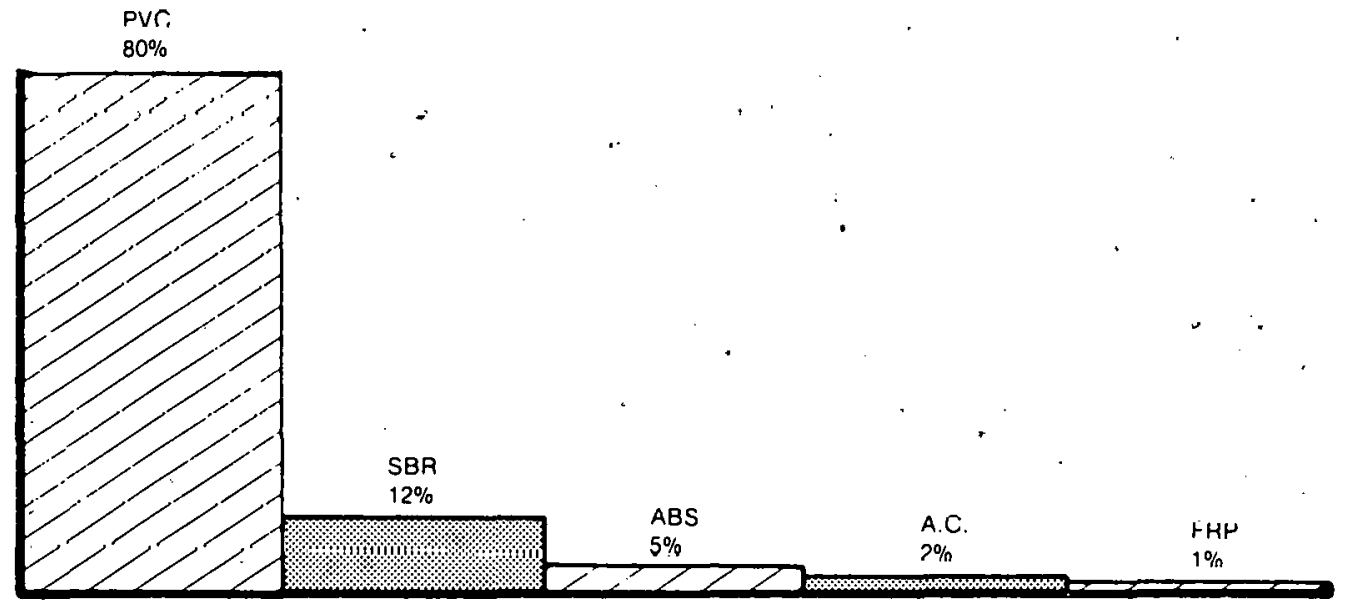

Figurc 2.1. Relative Use of Nonmetallic Materials for Water Wells in the United Stales 
Table 2.2

Recommended Casing Size for Various Well Yields Using Line Shaft Turbines 1800 RPM

$\begin{array}{rc}\text { Yield }(1 / \mathrm{s}) & \text { Recommended Casing Size } \\ \text { Less than } 6.3 & 152 \mathrm{~mm} \mathrm{I.D.} \\ 4.7-11.0 & 203 \mathrm{~mm} \mathrm{I.D.} \\ 9.5-25.0 & 254 \mathrm{~mm} \mathrm{I.D.} \\ 22.0-38.0 & 305 \mathrm{~mm} \mathrm{I.D.} \\ 38.0-82.0 & 405 \mathrm{~mm} \mathrm{O.D.} \\ 82.0-113.5 & 508 \mathrm{~mm} \mathrm{O.D.} \\ 113.5-189.0 & 610 \mathrm{~mm} \mathrm{O.D.} \\ 189.0+ & 914 \mathrm{~mm} \mathrm{0.D.}\end{array}$

The SDR of most thermoplastic well casing varies considerably with well depth and temperature. A small-diameter shallow well may use a casing with an SDR of 26 while the same casing in a deep well may require an SDR of 17. Table 2.3 shows the relationship between SDR classification and Schedule 40 and 80 classifications for various diameter thermoplastic casings.

Table 2.4.lists the cost per meter for various types and grades of casing and screens from 150 to $600 \mathrm{~mm}(6-24 \mathrm{in})$ in diameter. Also shown are the casing section lengths and types of joints most commonly used.

Although the prices in Table 2.4 were obtained from various manufacturers and suppliers, the costs should not be - considered binding selling prices. Where possible, costs are based on prices of $30 \mathrm{~m}(100 \mathrm{ft})$ of pipe for the third quarter of 1979. Actual prices charged by well drillers are slightly below list prices. Therefore, the calculated costs for casing and screen will be conservative values.

C. Transportation Costs

Transportation costs are determined by the distance to the nearest well casing supplier, type of transportation, weight per meter of casing, and whether smaller diameter casings are nested within larger diameter casing.

Distance depends on the region; it is shorter in heavily populated areas and longer in sparsely populated regions. Also, because certain types of casing (such as ABS, RPM, and wood laminate) are manufactured only at one or a few locations, their transportation costs can be quite high. 
Table 2.3

Wa71 Thickness and Tolerances for

Thermoplastic Water Well Casing Pipe

(Inches ${ }^{n}$ )

\begin{tabular}{|c|c|c|c|c|c|c|c|c|}
\hline \multirow{2}{*}{$\begin{array}{l}\text { Nominal } \\
\text { Pipe Size }\end{array}$} & \multicolumn{2}{|c|}{ SDR26 } & \multicolumn{2}{|c|}{ SDR21 } & \multicolumn{2}{|c|}{ SDR17 } & \multicolumn{2}{|c|}{ SDR13.5 } \\
\hline & Minimum & Tolerance & Mirimum & Tolerance & Minimurn & Tolerance & Minimum & Tolerance \\
\hline $\begin{array}{l}2 \\
21 / 2 \\
3\end{array}$ & $\begin{array}{l}\cdots \\
\cdots \\
\cdots\end{array}$ & $\begin{array}{l}\cdots \\
\cdots \\
\cdots\end{array}$ & $\begin{array}{l}0.113 \\
0.137 \\
0.167\end{array}$ & $\begin{array}{l}+0.020 \\
+0.020 \\
+0.020\end{array}$ & $\begin{array}{l}0.140 \\
0.169 \\
0.206\end{array}$ & $\begin{array}{l}+0.020 \\
+0.020 \\
+0.025\end{array}$ & $\begin{array}{l}0.176 \\
0.213 \\
0.259\end{array}$ & $\begin{array}{l}+0.021 \\
+0.026 \\
+0.031\end{array}$ \\
\hline $31 / 2$ & $\cdots$ & $\cdots$ & 0.190 & +0.023 & 0.235 & +0.028 & 0.296 & +0.036 \\
\hline 4 & 0.173 & $+0.02 \mathrm{I}^{-}$ & 0.214 & +0.026 & 0.265 & +0.032 & 0.333 & +0.040 \\
\hline $\begin{array}{l}5 \\
6\end{array}$ & $\begin{array}{l}0.214 \\
0.255 \\
\end{array}$ & $\begin{array}{l}+0.027 \\
+0.031\end{array}$ & $\begin{array}{l}0.265 \\
0.316\end{array}$ & $\begin{array}{l}+0.032 \\
+0.038\end{array}$ & $\begin{array}{l}0.327 \\
0.390\end{array}$ & $\begin{array}{l}+0.039 \\
+0.047\end{array}$ & $\begin{array}{l}0.412 \\
0.491\end{array}$ & $\begin{array}{l}+0.049 \\
+0.058\end{array}$ \\
\hline $\begin{array}{c}8 \\
10 \\
12\end{array}$ & $\begin{array}{l}0.332 \\
0.413 \\
0.490\end{array}$ & $\begin{array}{l}+0.040 \\
+0.050 \\
+0.059\end{array}$ & $\begin{array}{l}0.410 \\
0.511 \\
0.606\end{array}$ & $\begin{array}{l}+0.049 \\
+0.061 \\
+0.073\end{array}$ & $\begin{array}{l}0.508 \\
0.632 \\
0.750\end{array}$ & $\begin{array}{l}+0.061 \\
+0.076 \\
+0.090\end{array}$ & $\begin{array}{l}\cdots \\
\cdots \\
\cdots\end{array}$ & $\begin{array}{l}\cdots \\
\cdots \\
\cdots\end{array}$ \\
\hline
\end{tabular}

A The minimum is the lowest wall thickress of the well casing pipe at any cross section. All tolerances are on the plus side of the minimum requirement. Multiply by 25.4 to convert to millimeters.

$B$ Dimensions below the line meet or exceed Schedule 40 in SDR 13.5, 17, 21 and 26.

C Dimensions below the line meet or exceed Schedule 80 in SחR 1.3.5 and 17 . 
Table 2.4

Cost of Metallic and Non-Metallic Casings $(\$ / m)$

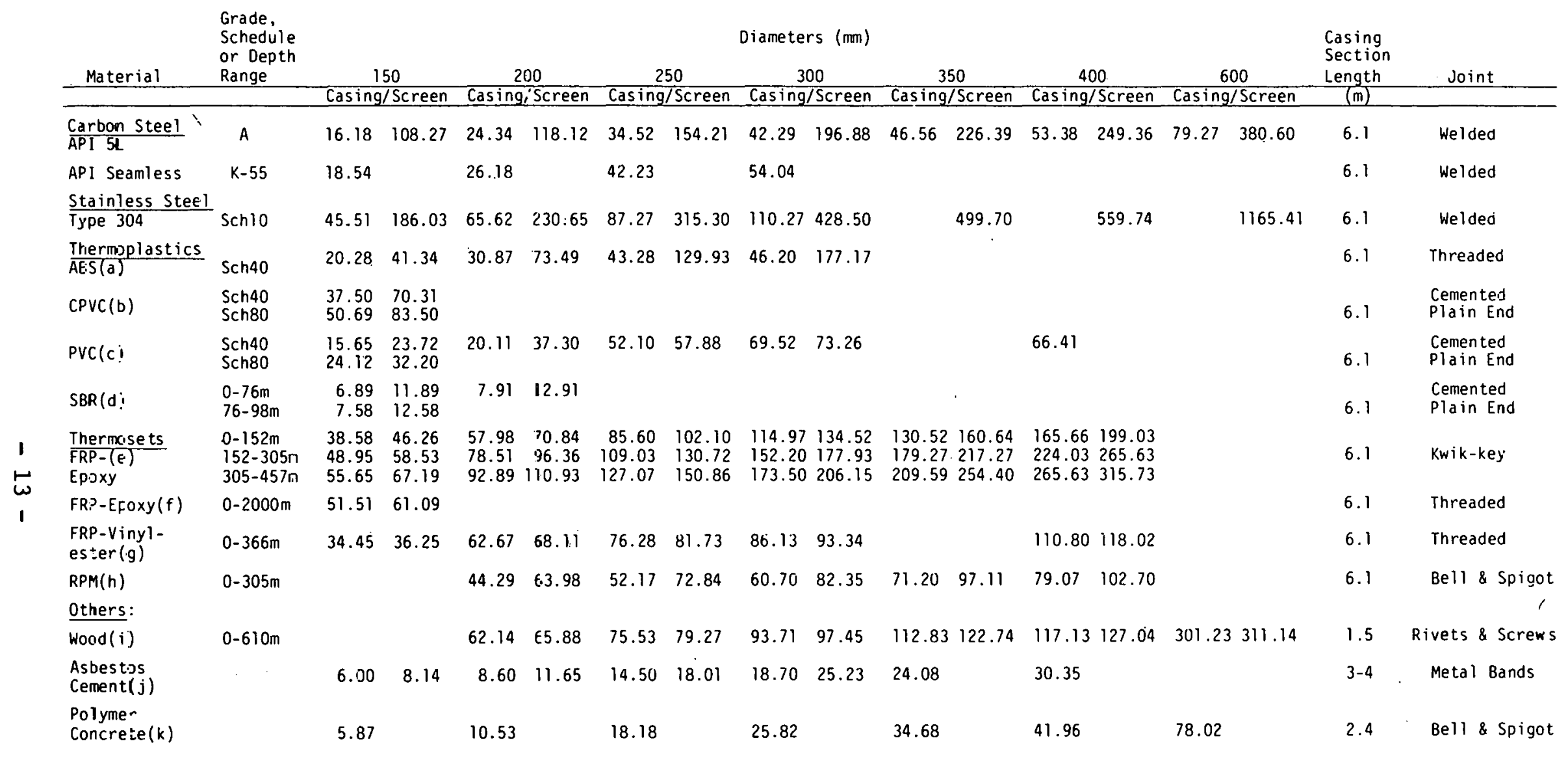

(a) DURAPLUS WELLCASE - Manufactured by Slocomb Piastic Pipe \& Products, Inc., Slocomb, Alabama.

(b) GEUN 3007 - Manufactured by Celanese Piping Systems, Inc. Hilliard, Ohio.

(c) JET STREAM 20376 - Nanufactured by Jet Stream Plastics, Siloam Springs, Arkansas.

(d) Manufactured by Jess \& Lowell, Denver, Colorado.

(e) KWIK-KEY CASING - Manufactured by Fiberglass Fiesources Corp., Farmingdale, New York.

(f) Manufactured by Fiberglass Systems, Inc., Big Springs, Texas.

(g) EOV Weli Casing - Manufactured by Burgess Well Co., Inc., Minden, Nebraska:

(h) TE-HITE Well Casing - Manufactured by Amoco Reinforced Plastics Co., Riverside, California.

(i) $S B=-$-obo Well Casing - Distributed by McCausey Lumber Co., Detroit, Michigan.

(j) TR.MNITE Class 3300 Sewer Pipe - Manufactured by Johns Manville Corp., Denver, Colorado.

(k) Not manufactured yet (Prices based on materials costs and fabrication cost for concrete pipe). 
One advantage of nonmetallic casing is that more casing can be transported per truckload by stacking small-diameter casing inside larger diameter casing. Also, flying the material in by plane or helicopter may prove to be less expensive in some cases.

Transportation costs are an important concern to the casing supplier and well driller but not necessarily to the well owner. Therefore, they will not be included in the cost comparisons.

D. Pumping Costs

Nonmetallic casing materidls, especially thermoplastic and fiberglass-reinforced plastic, have lower roughness coefficients than steel. This tends to reduce friction loss and, consequently, pumping costs. In addition, the friction loss in plastic casing remains relatively constant while friction loss in steel casing decreases over time due to incrustation and corrosion.

However, the difference in friction loss between steel and plastic casing may not be great enough to derive any significant savings in pumping costs. For example, the difference in friction head between FRP and old steel is .73 meter when pumping $31.5 \mathrm{l} / \mathrm{s}(500 \mathrm{gpm})$ through $305 \mathrm{~m}$ (1000 $\mathrm{ft}$ ) of $305 \mathrm{~mm}(12 \mathrm{in})$ pipe. This results in a savings of $\$ 94.30$ per year in pumping costs. If the steel is liew, savings drop to only $\$ 12.57$ per year. This small difference is not significant and will not be included in the cost comparison.

\section{E. Maintenance Charges}

Good well design, based on the awareness of hydrogeological conditions, type of geothermal application, and limitations of casing materials, is the key to successful well performance and, consequently, minimal and effect ive well maintenance. Based on conversations with numerous water well contractors and casing manufacturers in ditferent parts of the courtiry who have installed various types of nonmetallic casings for up to 16 years, these wells do not seem to require frequent maintenance. There were no reported instances of wells needing maintenance due to corrosion and/or scaling. One manufacturer stated that a downhole camera survey of an FRP vinylester well that had been in service for 16 years revealed no sign of deterioration. The same manufacturer reported good results using FRP vinylester in a 366-m (1200 ft) well that pumped 
water of $93^{\circ} \mathrm{C}\left(200^{\circ} \mathrm{F}\right)^{20}$. One driller reported no maintenance problems with PVC in an area where steel wells normally survive about five years. Steel wells installed in West Pakistan experienced decreased yields after six months of operation. This decline was due to scaling caused by sulfate-reducing bacteria. FRP casing and screens were then installed in 4,000 wells and these have performed successfully since 1965 with no maintenance problems. These wells have been operating with water containing 200 to 3,000 ppm salt 21 .

In another case, 203- and 254-mm (8 and 10 in) FRP casing was used in a $518-\mathrm{m}(1700 \mathrm{ft})$ deep well with little or no maintenance. Some companies have used FRP casing in salt water wells for 10 years with no deterioration or corrosion. On the other hand, steel casing in salt water wells requires constant attention 11. In addition, a well maintenance and rehabilitation survey by NWWA revealed that water well contractors, hydrogeologists, and well rehabilitation specialists recommended the use of plastic well casing and screen to prolong the life of a water well and to eliminate maintenance and rehabilitation 22. Thus, maintenance cost and frequency will not be a factor in the case of nonmetallic casings and screens. However, maintenance is very important when using metallic casing.

Table 2:5 lists the frequency of major maintenance for municipal water supply wells based on service records of steel wells of average design that are pumped continuously at or near their maximum capacities 22. The cost of major maintenance is considered equal to approximately 10 percent of the total current replacement cost. Major maintenance is necessary when the sustained yield or well efficiency declines by as much as 40 percent. It includes well redevelopment techniques such as acid treatment, sonic well cleaning, blasting, and replacing damaged casing and screen.

Table 2.5 al so indicates commonly encountered maintenance problems and aquifer types prevalent in the 10 ground-water regions. Maintenance problems are apparently much more closely related to aquifer type than to geographic location. Any variations caused by differences in mean annual temperature are masked by widely varying inorganic and organic chemical and biological factors at specific sites.

\section{F. Service Life}

The service life of a well casing depends on the type of casing material, thickness, conditions of use, maintenance, 
Table 2.5

\section{Maintenance Frequencies and Service Lives of Steel Wells in Ten Ground Water Regions}

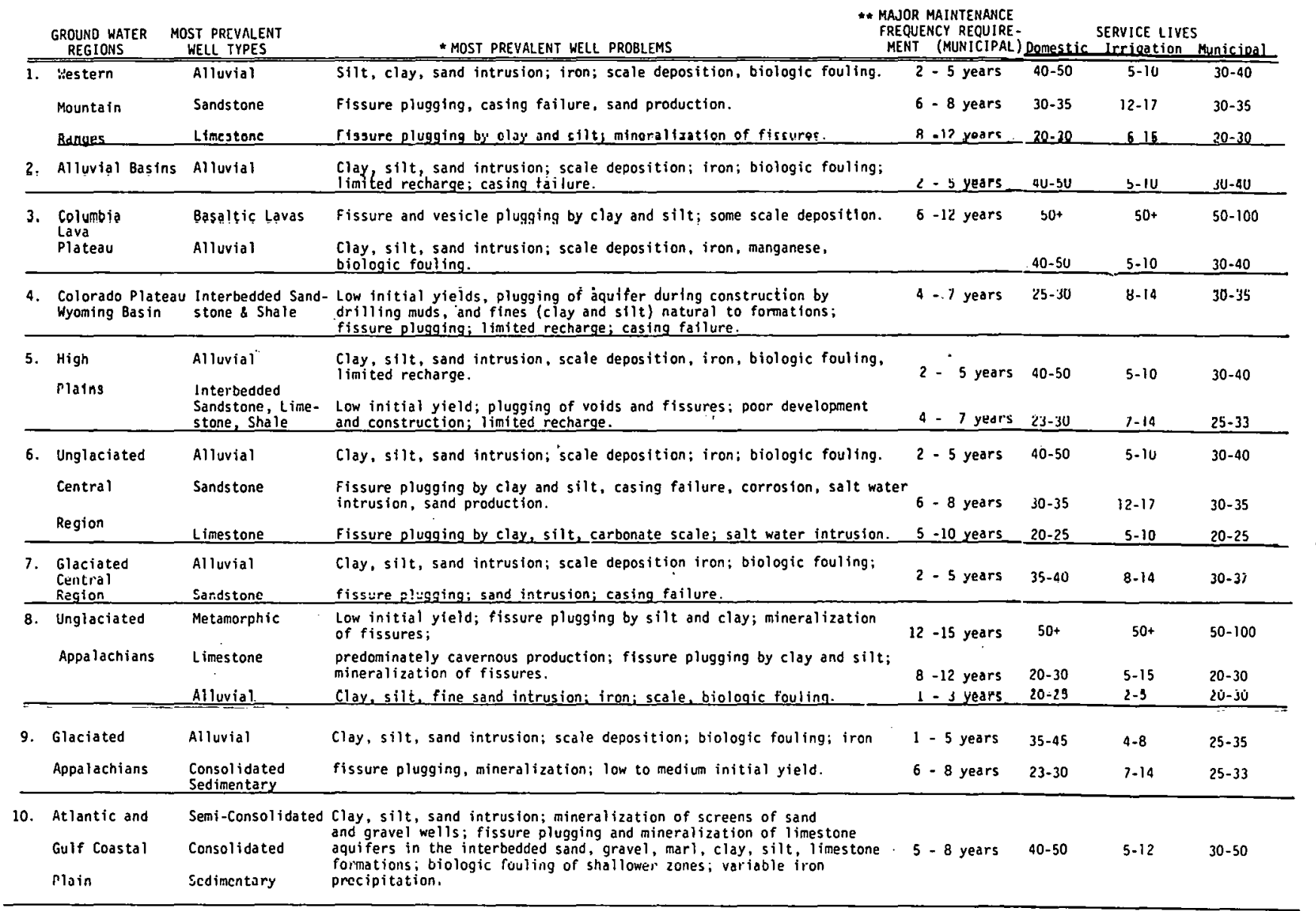

*. Exc?uding Pumps and declining water table.

* For wells being pumped at near capacity.

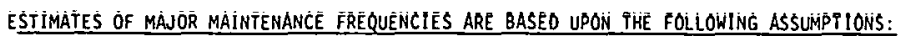

1. Wells are yielding at the highest sustained (24 hours per day, every day) yield that they are capable of producing.

2. Major maintenance is required when the sustained yield is 60 percent or less of the initial yield, or the efficiency decreases to the 60 percent level.

3. Major maintenance is considered to represent a cost expenditure of approximately 10 percent of the total current replacement cost. Minor maintenance is excluded.

4. Wells are designed in accordance with current practices, not necessarily in accordance with best available technology. 
and well design. Typical service lives for carbon steel domestic, irrigation, and municipal wells in various aquifers in the 10 ground-water regions are presented in Table 2.5. The large difference in service life between irrigation wells and domestic and municipal wells is due to the underdesigning of irrigation wells by using less expensive, thin-walled casing. This results in smaller initial cost, but the total cost over the lifetime of the irrigation project may be higher than if a better designed well had been initially installed.

The wells in Table 2.5 are predominantly drilled in shallow ground-water reservoirs of ambient temperature and quality. For geothermal applications, these conditions would be encountered only with wells supplying water to ground-water geothermal heat pumps. Low-temperature geothermal wells that encounter higher temperatures and acidity would have shorter service lives and more frequent maintenance.

Unfortunately, the lack of data has prevented any comprehensive study of the service lives and maintenance frequencies of geothermal wells. However, an economic model for geothermal cost analys is used performance data on metal pipes for corrosive fluid transmission to calculate geothermal well service lives 23 . For geothermal wells in oxygen-free brine of $150^{\circ} \mathrm{C}\left(302^{\circ} \mathrm{F}\right)$ and $\mathrm{pH} 7$ or greater, a service life of 30 years was calculated. This is similar to the minimum service life of most municipal wells in Table 2.5. Geothermal wells in lower temperature reservoirs would have lives approaching the maximum life of municipal wells in Table 2.5.

Most low-temperat ure geothermal resources have favorable composition; severe corrosion leading to frequent maintenance and short service life is a problem only when oxygen accidentally enters the wel $7 \mathrm{~s} 24$. Thus, values within the ranges for municipal wells should be valid for most. geothermal wells. However, wells that house downhole heat exchangers should have a range similar to domestic wells since continuous fluid production is not required for DHE wells. This was observed in one study where the service 1 ife of casing was 50 years.25

Corrosinn is usually a problem in acidic brines. With a $\mathrm{pH}$ between 6 and 7 and temperatures less than $93^{\circ} \mathrm{C}\left(200^{\circ} \mathrm{F}\right)$, 
the service life and maintenance frequency is approximately half; a $\mathrm{pH}$ between 4 and 6 with temperature below $93^{\circ} \mathrm{C}$ $\left(200^{\circ} \mathrm{F}\right)$ will give values about one-sixth as great. For acid brines with $\mathrm{pH}$ less than 4 and temperatures less than $150^{\circ} \mathrm{C}$ $\left(302^{\circ} \mathrm{F}\right)$, stainless steel should be used to regain the maximum service life 23 .

The use of nonmetallic materials in corrosive environments similar to geothermal wells is so recent that determining service lives based on past experience is impossible. FRP epoxy casing has been used for over 25 years to combat severe corrosion in hot brine wells. Wood casing has been used for about 30 years. The majority of nonmetallic casings have been on the market for less than 25 years. This does not mean that the materials will not last much longer. It simply means that the industry is still relativcly young and the service perind has not yet had time . to accumulate.

Based on conversations with water well contractors and manufacturers of nommetallic casings and screens, estimates of service lives for various materials have been obtained. Some of these estimates are based on laboratory tests. All of them assume ambient ground-water quality and temperature. PVC was given a service 1 ife greater than 40 years. Transite was reported to last between 25 and 40 years. RPM service life was estimated at 100 to 125 years. Laminated wood casing has a useful life greater than 30 years. FRP, $A B S$, polymer concrete, and SBR are reported to last indefinitely. For this study, all nonmetallics will be given a service life equal to stecl. This would be a conservative estimate for most nonmetallic casings.

It is assumed that the above materials will not be subject to temperatures, depths, and pressures that will result in casing collapse, and that higher grades will be used as temperature and depth increase. Ihus, certain materials will be removed from consideration for use in deep, hot water wells. For a more detailed discussion of the factor involved in determining maximum depth, see Appendix $C$ of Volume II.

G. Replacement Cost

A well will have to be replaced if maintenance cannot restore its initial yield for long periods of time or if the 
well suddenly fails due to collapse or excessive sand pumping. If the casing is too deteriorated, it may be impossible to pull it out of the hole so that new casing can be installed. In this case, the well will have to be abandoned and a new one drilled nearby. It is assumed that failure of low-temperature geothermal wells will result in their abandonment.

The cost of replacing a well will be more than the original cost due to inflation. This study assumes an inflation rate of 12 percent based on a recent well cost study 26. Past inflation figures indicate that this assumption is conservative.

\section{H. Interest Rate Factors}

All companies recognize that the value of money is of primary importance. They must be able to put a value on what they. will pay for money lent to them, or on what their funds can generate in terms of return on investment. It is immaterial whether one thinks in terms of payout period (i.e. how long it takes for an investment to return its incremental cost) or return on investment.

Future and present worth are fundamental to understanding the value of money. Present worth is the amount of money that must be invested today so that enough money is available in the future to replace or maintain the well throughout its service life. Future worth is the present worth compounded for " $n$ " years at a specific interest rate.

For the purposes of this study, an interest rate on borrowed money of 15 percent will be used.

I. Downt ime and Salvage

The cost of downtime during well maintenance or replacement is not.considered significant for two reasons: maintenance and replacement do not occur very often and lost production or energy savings can usually be made up.

The salvage value of a failed well casing is also not significant because the high cost of recovering the casing is many times greater than the salvage value. 


\section{BASIC EQUATIONS}

Several acceptable methods are available for economic comparisons of alternative corrosion-resistant materials. One common method is the equal-payment-series present worth analysis. This method uses a capital recovery factor which converts a zero time cost to an equivalent uniform end-of-year annual cost. The annual cost repays the initial expenditure with interest.

To derive the capital recovery factor, two relationships between present worth and future worth must be established. In the previous section, it was stated that future worth is equal to present worth compounded for $n$ years at a specific compound interest rate, i.

$$
F W=P W(1+i)^{n} \quad E q \cdot 2.1
$$

The uniform series of end-of-year deposits that must be made for $n$ years at compound interest to provide the required future sum can be expressed as:

$$
R=F W\left[i /(1+i)^{n}-1\right] \quad \text { Eq. } 2.2
$$

To find the future series end-of-year payments that will just recover a present sum $\mathrm{PW}$ over $n$ years with compound interest, the relationships in equations 2.1 and 2.2 are comblned as follows:

$$
R=P W\left[i(1+i)^{n} /(1+i)^{n}-1\right] \quad E q \cdot 2 \cdot 3
$$

This factor is referred to as the capital recovery factor. The value of $\underline{n}$ must be equal to the estimated service life of a material in order to make valid comparisons between materials. Thus, a short-lived material will have a larger capital recovery factor and the annual payments or annual cost will be iarger.

To calculate the maintenance costs, the effect of inflation over the lifetime of the well must be considered. If $A_{1}$ is the first year maintenance cost, then any future maintenance cost is equal t.n:

$$
A_{n}=A_{1}[1+(t \cdot n)] \quad E q \cdot 2.4
$$

where $t$ is the projected rate of inflation, and $\underline{n}$ is the number of years bcyond the first year. 
To calculate the total maintenance cost over the life of the well, $n$ is made equal to the estimated service life minus one year and the following relationship used:

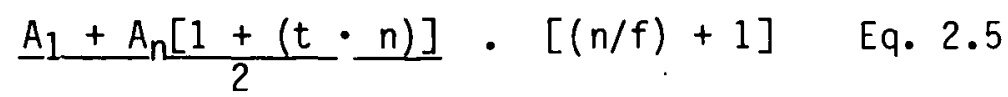

where $f$ is the frequency of maintenance. The factor $\left[(n / f)^{-}+1\right]$ is reduced to an integer. Thus, if it came out to be 3.67 , a value of 3 would be used.

The total maintenance cost is divided by the service life to give an annual cost. This is then added to the total annual capital cost of drilling and casing to give a total annual cost for the well.

Comparing this cost with that of a carbon steel well will give the amount of money saved each year by using the alternative material. This cost difference is then divided by the annual amount of thermal energy provided by the well to find the annual savings per gigajoule. 


\section{COST COMPARISONS}

The values and equations determined in Chapter 2 form the basis for comparisons of the total annual costs for geothermal wells constructed of various materials.

Examples of specific applications discussed in Appendix A will be used to determine the required well design, well depth, flow rate, water temperature, and energy demand. Where possible, actual case histories will be used to provide realistic value's.

Annual residential heating and cooling loads for each region were based on a residence with a floor space of 186 $\mathrm{m}^{2},\left(2000 \mathrm{ft}^{2}\right) \mathrm{R}-33$ insulation for ceilings, $\mathrm{R}-19$ insulation for walls and floors, double pane glass on all windows, and one infiltration change per hour.

Annual heating and cooling loads have been calculated for 24 select cities using degree-days and indoor temperature of $21.1^{\circ} \mathrm{C}\left(70^{\circ} \mathrm{F}\right)$ and an internal load of 1.47 $\mathrm{KJ} / \mathrm{sec}(5000 \mathrm{BTU} / \mathrm{hr})^{24}$. Annual heating loads for one acre of greenhouse were calculated using heat transfer coefficients of $17.6 \times 10^{-4}$ and $16.3 \times 10^{-4}$ joules/s. $\mathrm{cm}^{2} .{ }^{\circ} \mathrm{C}\left(1.22\right.$ and $1.13 \mathrm{BTU} / \mathrm{hr} . \mathrm{ft}{ }^{2}$. $\left.{ }^{\circ} \mathrm{F}\right)$ for the roof and walls, respectively, and a $-23^{\circ} \mathrm{C}\left(-9.4^{\circ} \mathrm{F}\right)$ design temperature. These loads were used to determine average loads for various systems in each region listed in Table 2.6. Al so shown in Table 2.6 are the annual costs of steel wells for all systems.

For those applications which require process heating, the annual heating load will be the same in all regions since the load is not dependent on climate.

Certain applications require fluid temperatures that are found extractable only in five regions in the western United states. Thus, for cost comparisons involving thesc applications only the five western regions will be usert.

For wells deeper than $610 \mathrm{~m}(2000 \mathrm{ft})$, larger drilling rigs are required and the costs 1 isted in Table 2.1 are not applicable. For these wells, recent costs estimates for deep geothermal well drilling 27 will be used. Regional variations in deep drilling cost are assumed to be insignificant. 
Table 2.6

Annual Cost of Steel We11s (1980 Dollars) Annual Energy Demand (Gigajoules)

For Geothermal' Systems

\begin{tabular}{|c|c|c|c|c|c|c|c|c|c|c|}
\hline System * & $\begin{array}{l}\text { Western } \\
\text { Mounta in } \\
\text { Ranges }\end{array}$ & $\begin{array}{l}\text { Alluvial } \\
\text { Basins }\end{array}$ & $\begin{array}{l}\text { Columbia } \\
\text { Lava } \\
\text { Plateau }\end{array}$ & $\begin{array}{l}\text { Colorado } \\
\text { Plateau }\end{array}$ & $\begin{array}{l}\text { High } \\
\text { Plains }\end{array}$ & $\begin{array}{l}\text { Glaciated } \\
\text { Central } \\
\text { Region } \\
\end{array}$ & $\begin{array}{l}\text { Unglaciated } \\
\text { Central } \\
\text { Region } \\
\end{array}$ & $\begin{array}{l}\text { Unglaciated } \\
\text { Appala- } \\
\text { chians } \\
\end{array}$ & $\begin{array}{l}\text { Glaciated } \\
\text { Appala- } \\
\text { chians }\end{array}$ & $\begin{array}{l}\text { Coastal } \\
\text { Plains } \\
\end{array}$ \\
\hline$A-1$ & $\begin{array}{r}1,339 \\
91\end{array}$ & $\begin{array}{r}1,786 \\
107\end{array}$ & $\begin{array}{r}1,169 \\
90\end{array}$ & $\begin{array}{r}1,176 \\
116\end{array}$ & $\begin{array}{c}1,738^{\circ} \\
105\end{array}$ & $\begin{array}{r}2,312 \\
100\end{array}$ & $\begin{array}{r}1,069 \\
109\end{array}$ & $\begin{array}{r}1,060 \\
\quad 113\end{array}$ & $\begin{array}{r}i, 840 \\
97\end{array}$ & $\begin{array}{r}1,726 \\
14\end{array}$ \\
\hline$A-2$ & $\begin{array}{l}2,052 \\
1,815\end{array}$ & $\begin{array}{l}1,828 \\
2,131\end{array}$ & $\begin{array}{l}2,385 \\
1,794\end{array}$ & $\begin{array}{l}2,100 \\
2,329\end{array}$ & $\begin{array}{l}1,781 \\
2,108\end{array}$ & $\begin{array}{l}2,474 \\
2,007\end{array}$ & $\begin{array}{l}2,141 \\
2,188\end{array}$ & $\begin{array}{l}2,298 \\
2,262\end{array}$ & $\begin{array}{l}1,846 \\
1,939\end{array}$ & $\begin{array}{l}2,098 \\
2,722\end{array}$ \\
\hline$A-3$ & $\begin{array}{l}68,419 \\
20,332\end{array}$ & $\begin{array}{l}68,419 \\
20,332\end{array}$ & $\begin{array}{l}68,419 \\
20,332\end{array}$ & $\begin{array}{l}68,419 \\
20,332\end{array}$ & $\begin{array}{r}68,419 \\
20,332\end{array}$ & $\begin{array}{l}68,419 \\
20,332\end{array}$ & $\begin{array}{l}68,419 \\
20,332\end{array}$ & $\begin{array}{l}68,419 \\
20,332\end{array}$ & $\begin{array}{l}68,419 \\
20,332\end{array}$ & $\begin{array}{l}68,419 \\
20,332\end{array}$ \\
\hline$B-1$ & $\begin{array}{l}918 \\
374\end{array}$ & $\begin{array}{r}820 \\
\quad 307\end{array}$ & $\begin{array}{l}903 \\
359\end{array}$ & $\begin{array}{l}820 \\
277\end{array}$ & . & & & 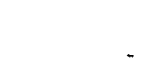 & & \\
\hline$c-1$ & $\begin{array}{l}34,478 \\
54,227\end{array}$ & $\begin{array}{l}36,548 \\
44,521\end{array}$ & $\begin{array}{l}39,793 \\
52,012\end{array}$ & $\begin{array}{l}36,907 \\
40,090\end{array}$ & & & $\begin{array}{l}35,768 \\
46,737\end{array}$ & & & \\
\hline$C-2$ & $\begin{array}{l}10,781 \\
49,850\end{array}$ & $\begin{array}{r}11,512 \\
.40,927\end{array}$ & $\begin{array}{l}10,536 \\
47,806\end{array}$ & $\begin{array}{r}9,931 \\
36,854\end{array}$ & . & & $\begin{array}{l}10,673 \\
42,960 .\end{array}$ & & · & $\begin{array}{r}9,227 \\
114,058\end{array}$ \\
\hline $0-1$ & $\begin{array}{r}24,605 \\
2,475,241\end{array}$ & $\begin{array}{r}24,605 \\
2,032,141\end{array}$ & $\begin{array}{r}24,605 \\
2,373,750\end{array}$ & $\begin{array}{r}24,605 \\
1,829,898\end{array}$ & 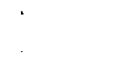 & & $\begin{array}{r}24,605 \\
2,134,687\end{array}$ & $\begin{array}{r}24,605 \\
1,611,776\end{array}$ & & $\begin{array}{r}24,605 \\
1,939,544\end{array}$ \\
\hline$E-1$ & $\begin{array}{l}35,298 \\
10,891\end{array}$ & $\begin{array}{r}37,529 \\
8,941\end{array}$ & $\begin{array}{l}40,609 \\
10,445\end{array}$ & $\begin{array}{r}37,765 \\
8,052\end{array}$ & & & $\begin{array}{r}36,767 \\
8,572\end{array}$ & & . & \\
\hline$E-2$ & $\begin{array}{l}27,605 \\
11,565\end{array}$ & $\begin{array}{r}24,381 \\
9,495\end{array}$ & $\begin{array}{l}27,481 \\
11,091\end{array}$ & $\begin{array}{r}28,280 \\
8,550\end{array}$ & & & $\begin{array}{r}24,322 \\
9,103\end{array}$ & $\begin{array}{r}35,554 \\
7,853\end{array}$ & & $\begin{array}{r}23,847 \\
5,557\end{array}$ \\
\hline$E-3$ & $\begin{array}{l}38,142 \\
47,304\end{array}$ & $\begin{array}{l}32,489 \\
38,837\end{array}$ & $\begin{array}{l}36,982 \\
45,365\end{array}$ & $\begin{array}{l}34,094 \\
34,972\end{array}$ & & & $\begin{array}{l}32,982 \\
37,232\end{array}$ & & & \\
\hline$E-4$ & $\begin{array}{l}32,530 \\
26,984\end{array}$ & $\begin{array}{l}34,072 \\
22,153\end{array}$ & $\begin{array}{l}33,454 \\
25,877\end{array}$ & $\begin{array}{l}31,028 \\
19,949\end{array}$ & & & $\begin{array}{l}30,227 \\
21,238\end{array}$ & & & \\
\hline$E-5$ & $\begin{array}{r}1,107 \\
330\end{array}$ & $\begin{array}{r}1,362 \\
271\end{array}$ & $\begin{array}{r}1,077 \\
316\end{array}$ & $\begin{array}{l}992 \\
244\end{array}$ & & & $\begin{array}{l}882 \\
260\end{array}$ & & & \\
\hline$F-1$ & $\begin{array}{r}29,448 \\
9,041\end{array}$ & $\begin{array}{r}29,729 \\
9,041\end{array}$ & $\begin{array}{r}33,880 \\
9,041\end{array}$ & $\begin{array}{r}31,505 \\
9,041\end{array}$ & & & $\begin{array}{r}30,519 \\
9,041\end{array}$ & & & \\
\hline$r-2$ & $\begin{array}{r}11,700 \\
329,160\end{array}$ & $\begin{array}{r}13,210 \\
329,160\end{array}$ & $\begin{array}{r}12,55 j \\
329,160\end{array}$ & $\begin{array}{r}12,5000 \\
329,160\end{array}$ & & & $\begin{array}{r}12,194 \\
329,160\end{array}$ & & & \\
\hline$F-3$ & $\begin{array}{l}229,687 \\
907,300\end{array}$ & $\begin{array}{l}257,863 \\
907,300\end{array}$ & $\begin{array}{l}264,257 \\
907,300\end{array}$ & $\begin{array}{l}245,730 \\
907,300\end{array}$ & & & $\begin{array}{l}238,053 \\
907 ; 300\end{array}$ & & & \\
\hline$F-4$ & $\begin{array}{r}47,116 \\
369,250\end{array}$ & $\begin{array}{r}50,092 \\
369,250\end{array}$ & $\begin{array}{r}54,206 \\
369,250\end{array}$ & $\begin{array}{r}50,406 \\
369,250\end{array}$ & & & $\begin{array}{r}48,831 \\
369,250\end{array}$ & & & \\
\hline$F-5$ & $\begin{array}{r}188,462 \\
474,750\end{array}$ & $\begin{array}{l}200,322 \\
474,750\end{array}$ & $\begin{array}{l}223,133 \\
474,750\end{array}$ & $\begin{array}{l}201,618 \\
474,750\end{array}$ & & & $\begin{array}{l}195,325 \\
474,750\end{array}$ & & & \\
\hline$f-6$ & $\begin{array}{r}4,263,900 \\
233,166\end{array}$ & $\begin{array}{r}4,263,900 \\
233,166\end{array}$ & $\begin{array}{r}4,263,900 \\
233,166\end{array}$ & $\begin{array}{r}4,263,900 \\
233,166\end{array}$ & & & $\begin{array}{r}4,263,900 \\
233,166\end{array}$ & & & \\
\hline
\end{tabular}

* Letter-number code refers to the appropriate subheadings in this chapter. 


\section{A. Ground Water Geothermal Heat Pumps}

1. Single Dwelling 28

The following assumptions were used in calculating well costs for this application: One production well and one injection well are required. Diameter and depth of both wells are the same, $152 \mathrm{~mm}$ and $46 \mathrm{~m}$ ( 6 in and $150 \mathrm{ft}$ ). Flow rate is $.5 \mathrm{l} / \mathrm{s}(8 \mathrm{gpm})$ and well lhead temperature is the average ground water temperature for each region. The type of aquifer is the most widespread type in each region.

Table 2.7 summarizes the results of the cost comparison for a single dwelling ground water geothermal heat pump system.

\section{District Heating System 29}

Well design for this system is based on a 20-home module. One production well and one injection well of the same diameter $152 \mathrm{~mm}(6 \mathrm{in})$ and depth, $46 \mathrm{~m}$ (150 ft) are required. The production well delivers $6.3 \mathrm{l} / \mathrm{s}(100 \mathrm{gpm})$ of ambient temperature groundwater to heat pump units in each home. The injection well discharges hot or cold water to the aquifer which is assumed to be alluvium for all regions. 
Table 2.7

\section{Savings Per Year (1980 Dollars)}

\section{Savings/Gigajoule/Year}

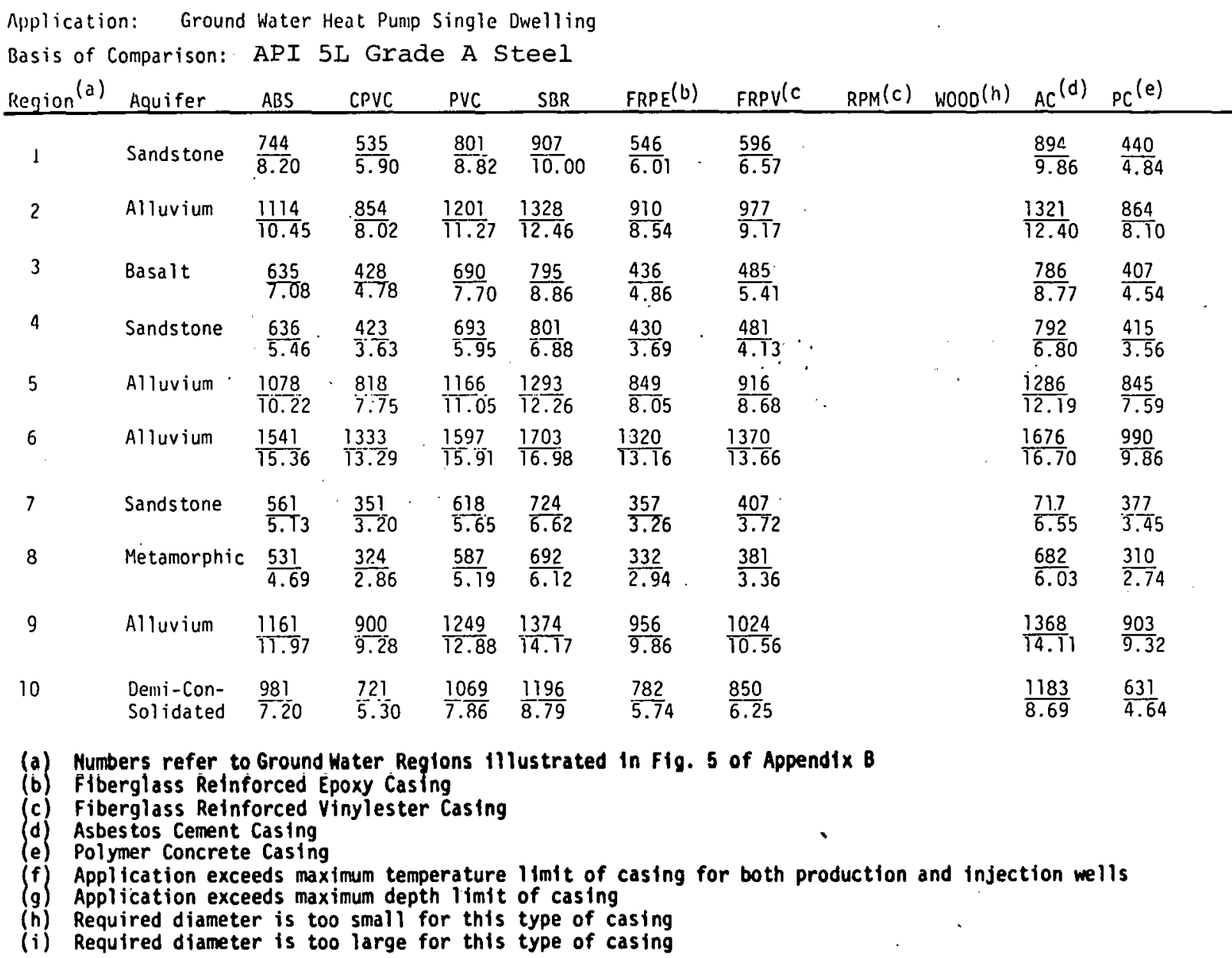


The results of the cost comparison for this system are summarized in Table 2.8.

3. Industrial or Commercial Process Heating 2

For this system a $914 \mathrm{~m}(3000 \mathrm{ft})$ deep, $203 \mathrm{~mm}-(8 \mathrm{in}-)$ diameter well supplies $20.5 \mathrm{l} / \mathrm{s}(325 \mathrm{gpm})$ of $38^{\circ} \mathrm{C}\left(100^{\circ} \mathrm{F}\right)$ water to a Templifier heat pump which increases the temperature of the water for process heating. An injection well of the same dimensions disposes cooled water into the aquifer which is the most permeable deep aquifer in each region.

Table 2.9 lists the results of the cost comparison of this application.

B. Downhole Heat Exchanger

1. Four-home module

Design factors for the DHE systems have been established in previous studies $16,25,30$. Onty one $61 \mathrm{~m}(200 \mathrm{ft})$ well i.s required and flow rate is not a factor since there is no fluid production. 'The diameter of the casing is $203 \mathrm{~mm}$ ( 8 $\mathrm{in}$ ) and the diameter of the borehole is $254 \mathrm{~mm}(10 \mathrm{in})$. The reservoir temperature used for this application is $66^{\circ} \mathrm{C}$ $\left(151^{\circ} \mathrm{F}\right)$. Since only four regions contain shallow aquifers with this temperature, only those regions will be 
Table 2.8

Savings Per Year (1980 Dollars)

Savings/Gigajoule/Ỵear

Mpplication: Districe Heating with Ground Water Heat Pump

Basis of Comparison: API 5 L Grade A Steel

Region(a) Aquifer. ABS CPVC PVC SBR FRPE(b) $\operatorname{FRPV}^{(c)} \quad \operatorname{RPM}^{(h)} \operatorname{WOOD}^{(h)} \operatorname{AC}^{(d)} \operatorname{PC}^{(e)}$

\begin{tabular}{|c|c|c|c|c|c|c|c|c|c|}
\hline 1 & Alluvium & $\frac{1337}{.74}$ & $\frac{1087}{.60}$ & $\frac{1413}{.78}$ & $\frac{1538}{.84}$ & $\frac{1124}{.62}$ & $\frac{1187}{.65}$ & $\frac{1523}{.84}$ & $\frac{985}{.54}$ \\
\hline 2 & Alluvium & $\frac{1172}{.55}$ & $\frac{922}{.43}$ & $\frac{1249}{.59}$ & $\frac{1373}{.64}$ & $\frac{955}{.45}$ & $\frac{1018}{.48}$ & $\frac{1363}{.64}$ & $\frac{902}{.42}$ \\
\hline 3 & Alluvium & $\frac{1582}{.88}$ & $\frac{1332}{.74}$ & $\frac{1658}{.92}$ & $\frac{1783}{1.00}$ & $\frac{1457}{.81}$ & $\frac{1520}{.85}$ & $\frac{1762}{.98}$ & $\frac{1100}{.67}$ \\
\hline 4 & Alluvium & $\frac{1373}{.59}$ & $\frac{1122}{.48}$ & $\frac{1449}{.62}$ & $\frac{1573}{.67}$ & $\frac{1161}{.50}$ & $\frac{1223}{.53}$ & $\frac{1558}{.67}$ & $\frac{1003}{.43}$ \\
\hline 5 & Alluvium & $\frac{1138}{.54}$ & $\frac{888}{.42}$ & $\frac{1214}{.58}$ & $\frac{1338}{.64}$ & $\frac{920}{.44}$ & $\frac{983}{.47}$ & $\frac{1329}{.63}$ & $\frac{885}{.42}$ \\
\hline 6 & Alluvium & $\frac{1647}{.82}$ & $\frac{1397}{.70}$ & $\frac{1723}{.86}$ & $\frac{1848}{.92}$ & $\frac{1442}{.72}$ & $\frac{1505}{.75}$ & $\frac{1826}{.91}$ & $\frac{1141}{.57}$ \\
\hline 7 & Alluvium & $\frac{1403}{.64}$ & $\frac{1152}{.53}$ & $\frac{1479}{.58}$ & $\frac{1603}{.73}$ & $\frac{1191}{.54}$ & $\frac{1254}{.57}$ & $\frac{1587}{.73}$ & $\frac{1018}{.47}$ \\
\hline 8 & Alluvium & $\frac{1518}{.67}$ & $\frac{1268}{.56}$ & $\frac{1594}{.70}$ & $\frac{1719}{.76}$ & $\frac{1310}{.58}$ & $\frac{1373}{.61}$ & $\begin{array}{r}1700 \\
-.75\end{array}$ & $\frac{1076}{.48}$ \\
\hline 9 & Alluvium & $\frac{1186}{.61}$ & $\frac{936}{.48}$ & $\frac{1262}{.65}$ & $\frac{1387}{.72}$ & $\frac{969}{.50}$ & $\frac{1032}{.53}$ & $\frac{1376}{.71}$ & $\frac{909}{.47}$ \\
\hline 10 & Alluvium & $\frac{1374}{.51}$ & $\frac{1123}{. .41}$ & $\frac{1450}{.53}$ & $\frac{1574}{.58}$ & $\frac{1162}{.03}$ & $\frac{1224}{.45}$ & $\frac{1327}{.49}$ & $\frac{1004}{.37}$ \\
\hline
\end{tabular}

(a) Numbers refer to Ground Water Regions Illustrated in Fig. 5 of Appendix B

(b) Fiberglass ketnforced Epoxy Casing

(c) Fiberglass Reinforced Vinylester Casing

(d) Asbestos Cement Casing

(e) Polymer Concrete Casing

(f) Application exceeds maximum temperature limit of casing for both production and injection wells

g) Application exceeds maximum depth limit of casing

(h) Required diameter is too small for this type of casing

(i) Required diameter is too large for this type of casing 
Table 2.9

Savings Per Year (1980 Dollars)

Savings/Gigajoule/Year

Application; Industrial Heat Pump

Basis of Comparison: API 5I Grade A Stee1

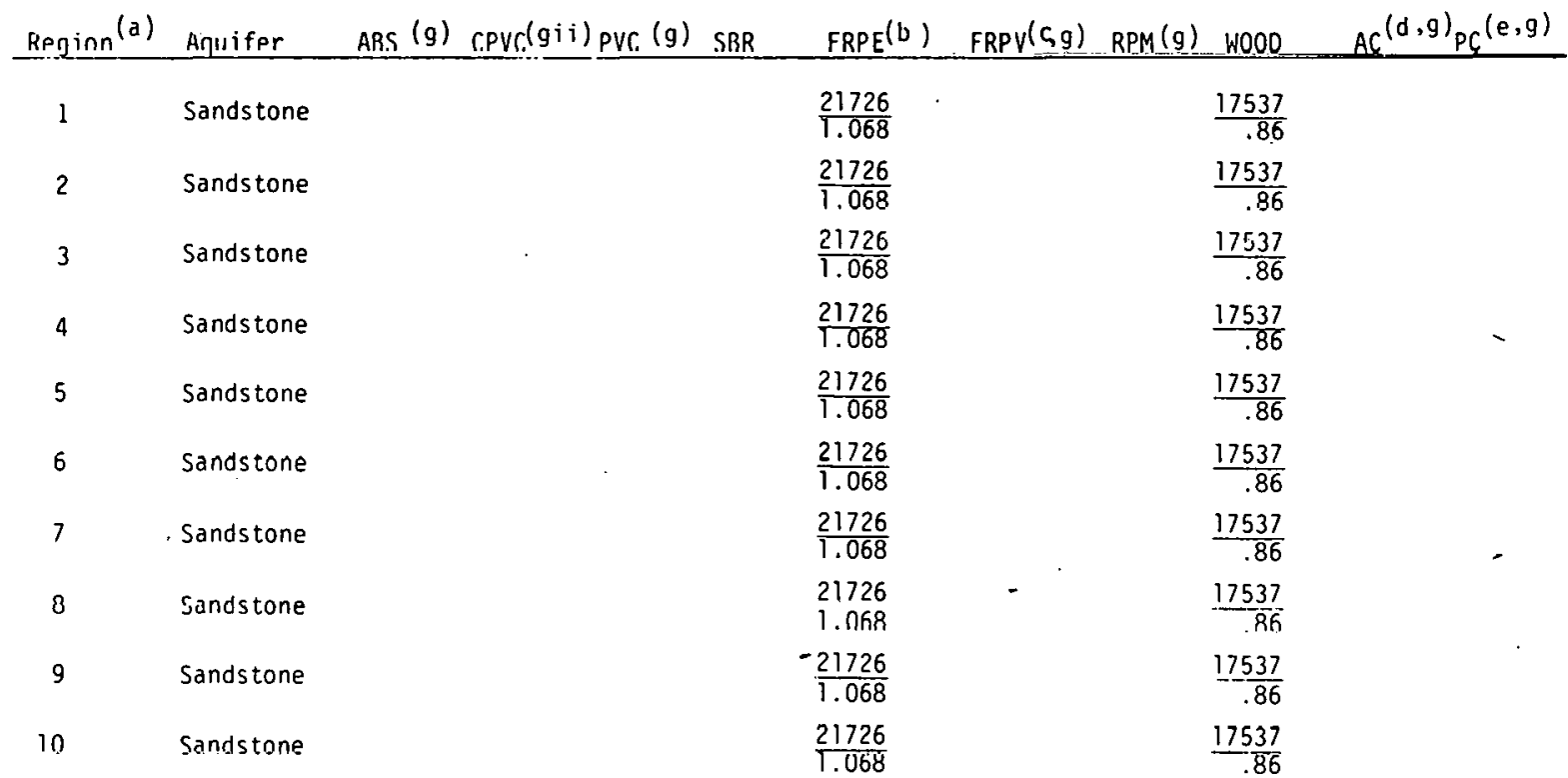

(a) Numbers refer to Ground Water Regions illustrated in Fig. 5 of Appendix $B$

(b) Fiberglass Reinforced Epoxy Casing

(c) Fiberglass Reinforced Vinylester Casing

(d) Asbestos Cement Casing

(e) Polymer Concrete Casing

(f) Application exceeds maximum temperature limit of casing for both production and injection wells

(g) Application exceeds maximum depth limit of casing

(h) Required diameter is too small for this type of casing

(i) Required diameter is too large for this type of casing 
Table 2.10

\section{Savings Per Year (1980 Dollars)}

Savings/Gigajoule/Year

Application: Downhole Heat Exchanger - 4 Dwellings

Bas is of Comparison:API 5 L Grade A Steel

Region (a) Aquifer ABS CPVC (i) PVC (f) $\operatorname{SBR}(f) \operatorname{FRPE}(b) \quad F R P(c) \quad R P M \quad W O O D \quad A C$ (d) $P C$ (e)

$\begin{array}{llrrrrrrrr}1 & \text { Sandstone } & \frac{389}{1.04} & \frac{170}{.45} & \frac{131}{.35} & \frac{260}{.69} & \frac{120}{.32} & \frac{595}{1.59} & \frac{281}{.75} \\ 3 & \text { Alluvium } & \frac{324}{1.05} & \frac{102}{.33} & \frac{62}{20} & \frac{197}{.64} & \frac{54}{.18} & \frac{553}{1.73} & \frac{263}{.86} \\ 4 & \text { Basait } & 1 \frac{380}{23} & \frac{161}{.52} & \frac{122}{.40} & \frac{252}{.82} & \frac{112}{.36} & \frac{586}{1.91} & \frac{281}{.91} \\ & \text { Sandstone } & \frac{332}{1.20} & \frac{110}{.40} & \frac{71}{26} & \frac{206}{.75} & \frac{63}{.23} & \frac{541}{1.95} & \frac{281}{1.01}\end{array}$

\footnotetext{
(a) Numbers refer to Ground Water Regions illustrated in F1g. 5 of Appendix B

(b) Fiberglass Reinforced Epoxy Casing

(c) Fiberglass Reinforced Vinylester Casing

(d) Asbestos Cement Casing

(e) Polymer Concrete Casing

(f) Application exceeds maximum temperature limit of casing for both production and injection wells

(g) Application exceeds maximum depth limit of casing

(h) Required diameter is too small for this type of casing

(i) Required diameter is too large for this type of casing
} 
considered. The aquifer will be the most common consolidated rock in the region except in the Alluvial Basins Region where it will be unconsolidated alluvium.

Table 2.10 lists the results of the cost comparisons. C. Surface Heat Exchanger

1. District Heating System - 1000 buildings 16

For this system, 1,000 homes are heated by exchange with $82^{\circ} \mathrm{C}\left(180^{\circ} \mathrm{F}\right)$ water supplied by two $203 \mathrm{~mm}(8 \mathrm{in}), 610 \mathrm{~m}-$ $\left(2000 \mathrm{fl}-\right.$ ) deep wells al a rale of $31.51 / \mathrm{s}(500 \mathrm{gpm}) .54^{\circ} \mathrm{C}$ $\left(129^{\circ} \mathrm{F}\right)$ discharge water is disposed. of through one injection well with the same dimensions às the production wells. The same four regions and types of aquifers used in the case of downhole heat exchangers will be used in this system. 2.11 .

Results of the cost comparison can be found in Table

2. District Heating System - 125 buildings 17

This system, proposed for Midland, S.D. requires one 152 $\mathrm{mm}$ ( $6 \mathrm{in}$ ) artesian well with a depth of $610 \mathrm{~m}(2000 \mathrm{ft})$ and a flow rate of $57.1 .1 / \mathrm{s}(905 \mathrm{gpm})$. No injection wells are required. Wel thead temperature is $71^{\circ} \mathrm{C}\left(160^{\circ} \mathrm{F}\right)$, which is sufficient to heat .125 buildings using surface heat exchangers.

The four western regions will be used and the aquifer is the most typical artesian aquifer in each region.

Table 2.12 summarizes the cost comparison results:

D. Surface Heat Exchanger plus Heat Pump

1. District Heating System - 2,500 apartments

An economic analysis of geothermal district heating in the Paris Basin 31 showed that the optimum number of apartments is 2,500. Total flow requirement varies from $2 / .8$ to $55.5 \mathrm{l} / \mathrm{s}(440$ to $880 \mathrm{gpm})$ of $65^{\circ} \mathrm{C}\left(149^{\circ} \mathrm{F}\right)$ water, Well design for this system has been recently reported 32 . Due to the highly corrosive nature of the geothermal fluid $(23,000 \mathrm{ppm} \mathrm{NaCl})$, fiberglass casing was required. Well depth is $2,000 \mathrm{~m}$ (6562. ft.), diameter is $203 \mathrm{~mm}$ (8 in). 
Table 2.11

Savings Per Year (1980 Dollars)

Savings/Gigajoule/Year

Application: SHE - 1000-Building Heating System

Basis of Comparison: API Grade K-55 Steel

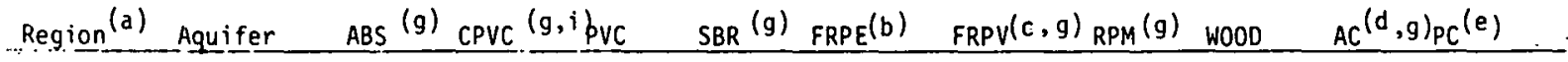

$1 \quad$ Sandstone

2 Alluvium

$\frac{9962}{. .18}$

$\underline{12056}$

. $\frac{14290}{32}$

$\frac{10425}{.19}$

.22

3 Basalt

12334 .

$\underline{13686}$

16960

4 Sandstone

11918

.3

7 Sandstone

$\frac{11918}{.30}$

.28

$\frac{13555}{26}$

$\frac{14057}{30}$

(a) Numbers refer to Ground Water Regions illustrated in Fig. 5 of Appendix B

(b) Fiberglass Reinforced Epoxy Casing

(c) Fiberglass Reinforced Vinylester Casing

(d) Asbestos Cement Casing

(e) Polymer Concrete Casing

(f) Application exceeds maximum temperature 1 imit of casing for both production and injection wells

(g) Application exceeds maximum depth limit of casing

(h) Required diameter is too small for this type of. casing

(i) Required diameter is too large for this type of casing

Table 2.12

\section{Savings Per Year (1980 Dollars) \\ Savings/Gigajoule/Year}

Application: SHE - 125-Building Heating System

Basis of Comparison: API $5 \mathrm{~L}$ Grade A Steel

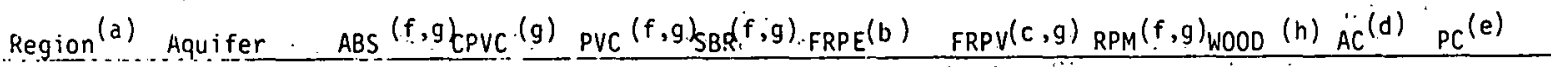

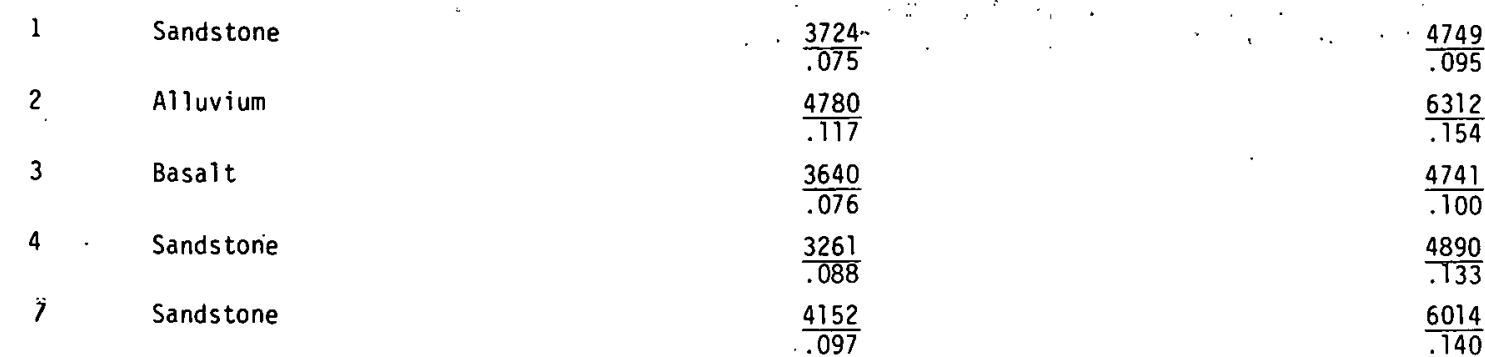

(a) Numbers refer to Ground Water Reglons 11 lustrated in Fig. 5 of Appendix B

(b) Fiberglass Reinforced Epoxy Casing

(c) Fiberglass Reinforced Vinylester Casing

(d) Asbestos Cement Casing

(e) Polymer Concrete Casing

(f) Application exceeds maximum temperature limit of casing for both production and injection wells

g Application exceeds maximum depth limit of casing

(h) Required diameter is too small for this type of casing

(i) Required diameter is too large for this type of casing 
Table 2.13

Savings Per Year (1980 Dollars)

Savings/Gigajoule/Year

Application: SHE \& Heat Pump - Apartment Complex Heating

Basis of Comparison: Type 304 Stainless Steel

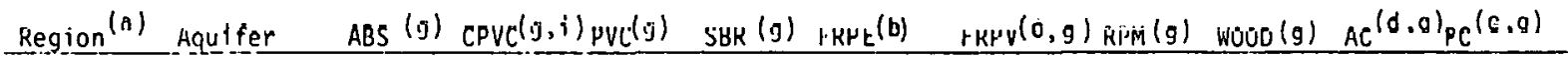

1 Sandstone 2485

.0010

2 Sandstone 2485

3 Sandstone 2485

Sandstone

$\frac{.0014}{.0014}$

7 Sandstone 2485

8 Sandstone 2485

.0015

10 Sands tone $\quad 2485$

.0010

(a) Numbers refer to Ground Water Regions illustrated in Fig. 5 of Appendix $B$

(b) Fiberglass Reinforced Epoxy Casing

(c) Fiberglass Reinforced Vinylester Casing

(d) Asbestos Cement Casing

(e) Polymer Concrete Casing

(f) Application exceeds maximum temperature limit of casing for both production and injection wells

(g) Application exceeds maximum depth limit of casing

(h) Required diameter is too small for this type of casing

(i) Required diameter is too large for this type of casing 
Cost comparisons, based on type 304 stainless steel rasing and screen are shown in Table 2.13.

E. Direct Heating

1. 15-Acre Greenhouse Complex 17

For this system, a single $203 \mathrm{~mm}$ ( 8 in) injection well could handle up to three $203 \mathrm{~mm}$ ( $8 \mathrm{in}$ ) production well $\mathrm{s}$. Assuming a well depth of $457 \mathrm{~m}(1500 \mathrm{ft})$, a well head temperature of $93^{\circ} \mathrm{C}\left(200^{\circ} \mathrm{F}\right)$ and a flow of $31.5 \mathrm{l} / \mathrm{s}(500 \mathrm{gpm})$ per well, this system would supply a 15-acre greenhouse complex which is the optimum size for such a system. Injection temperature is $32^{\circ} \mathrm{C}\left(90^{\circ} \mathrm{F}\right)$.

A permeable aquifer is used in each of the four western regions due to the large volume of water required.

Table 2.14 lists the results of the cost comparisons for this system.

\section{Two-Acre Greenhouse 17}

This system would require el even $152 \mathrm{~mm}$ ( 6 in), $61 \mathrm{~m}-$ (200 ft-) deep production wells supplying a total of $250 \mathrm{l} / \mathrm{s}$ $(3,960 \mathrm{gpm})$ of $43^{\circ} \mathrm{C}\left(109^{\circ} \mathrm{F}\right)$ fluid which directly heats the greenhouse and is disposed of at a temperature of $32^{\circ} \mathrm{C}$ $\left(90^{\circ} \mathrm{F}\right)$ through eleven injection wells of the same dimensions as the production wells.

Due to the lower temperature requirements; this system can be used in seven regions. An alluvial aquifer is assumed for each region except Region 7 .

Results of the cost comparison for this system are shown in Table 2.15 .

3. Municipal Heating System - 283 homes 33 .

District heating with $77^{\circ} \mathrm{C}\left(171^{\circ} \mathrm{F}\right)$ geothermal fluid has been done successfully for over 40 years in Boise, Idaho. A system comprised of a $305 \mathrm{~mm}$ (12 in), $610 \mathrm{~m}-(2000 \mathrm{ft}-$ ) deep well supplying $63.11 / \mathrm{s}(1,000 \mathrm{gpm})$ of $77^{\circ} \mathrm{C}\left(171^{\circ} \mathrm{F}\right)$ water and a return well of the same dimensions could heat 283 homes. 
Table 2.14

Savings Per Year (1980 Dollars)

Savings/Gigajoule/Year

Application: 15 - Acre Greenhouse

Basis of Comparison: API Grade K-55 Stee $]$

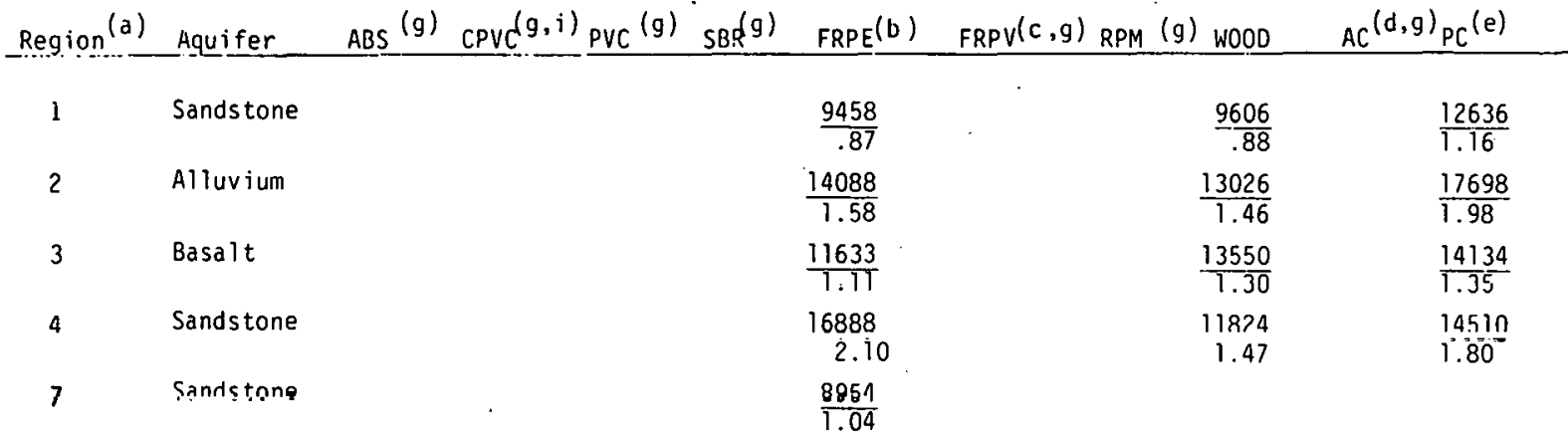

(a) Mumhers refer to Ground Hater Kegions lllustrated in Fig. 5 of Appendix $B$

(b) Ftberglass Reinforced Epoxy Casing

(c) Fiberglass Reinforced Vinylester Casing

d) Asbestos Cement Casing

(e) Polymer Concrete Casing

(f) Application exceeds maximum temperature 1 imit of casing for both production and injection wells

g) Application exceeds maximum depth limit of casing

(h) Required diameter is too small for this type of casing

(i) Required diameter is too large for this type of casing

Table 2.15

Savings Per Year (1980 nollars)

Savings/Gigajoule/Year

Application: 2 - Acre Greenhouse

Basis of Comparison: API $5 L$ Grade A Steel

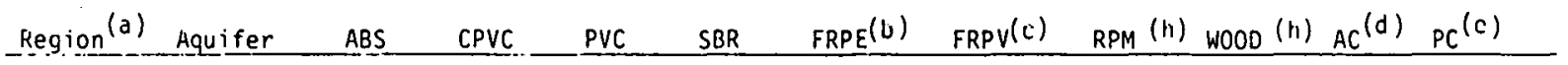

\begin{tabular}{|c|c|c|c|c|c|c|c|c|c|}
\hline 1 & Alluvium & $\frac{15258}{1.32}$ & $\frac{10557}{.91}$ & $\frac{17510}{1.52}$ & $\frac{19607}{1.70}$ & $\frac{13298}{1.15}$ & $\frac{14732}{1.27}$ & $\frac{19647}{1.70}$ & $\frac{11921}{1.03}$ \\
\hline 2 & Alluvium & $\frac{12909}{1.11}$ & $\frac{8208}{.86}$ & $\frac{15160}{1.59}$ & $\frac{17238}{1.07}$ & $\begin{array}{r}10885 \\
1.15\end{array}$ & $\begin{array}{r}12319 \\
1.30\end{array}$ & $\frac{17358}{1.83}$ & $\frac{10774}{1.14}$ \\
\hline 3 & Alluvium & $\frac{14038}{1.21}$ & $\frac{9405}{.84}$ & $\frac{16257}{1.47}$ & $\frac{18324}{1.65}$ & $\begin{array}{r}12195 \\
1.10\end{array}$ & $\frac{13608}{1.22}$ & $\frac{18268}{1.65}$ & $\frac{8985}{.81}$ \\
\hline 4 & Alluvium & $\frac{15752}{7.84}$ & $\frac{11051}{1.29}$ & $\frac{18004}{2.10}$ & $\frac{20101}{2.35}$ & $\frac{13802}{1.61}$ & $\frac{15236}{1.78}$ & $\frac{20125}{2.35}$ & $\frac{12160}{1.42}$ \\
\hline 7 & Sands tone & $\begin{array}{r}11630 \\
1.20\end{array}$ & $\begin{array}{r}6929 \\
.70\end{array}$ & 13881 & $\frac{15979}{1.75}$ & $\frac{12597}{1.38}$ & $\frac{11127}{1.22}$ & $\frac{15990}{1.75}$ & $\begin{array}{r}7810 \\
.86\end{array}$ \\
\hline 8 & Alluvium & $\frac{22249}{2.83}$ & $\frac{17548}{2.24}$ & $\frac{24500}{3.12}$ & $\frac{26598}{3.38}$ & $\frac{20359}{2.60}$ & $\frac{21793}{2.78}$ & $\frac{26568}{3.38}$ & $\frac{17588}{2.24}$ \\
\hline 10 & Alluvium & $\begin{array}{r}11306 \\
2.04\end{array}$ & $\frac{6605}{1.18}$ & $\frac{13557}{2.44}$ & $\frac{15661}{2.82}$ & $\frac{9359}{1.69}$ & $\frac{10793}{1.94}$ & $\frac{15682}{2.82}$ & $\frac{7700}{1.38}$ \\
\hline
\end{tabular}

(a) Numbers refer to Ground Water Regions lllustrated in Fig. 5 of Appendix $B$

(b) Fiberglass Reinforced Epoxy Casing

(c) Fiberglass Reinforced Vinylester Casing

(d) Asbestos Cement Casing

(e) Polymer Concrete Casing

(f) Application exceeds maximum temperature $11 \mathrm{mit}$ of casing for both production and injection welis

(g) Application exceeds maximum depth limit of casing

(h) Required diameter is too small for this type of casing

(i) Required diameter is too large for this type of casing 
Table 2.16

\section{Savings Per Year (1980 Dollars)}

Savings/Gigajoule/Year

Application: Direct Heating - 283 Homes

Basis of Comparison: API $5 \mathrm{~L}$ Grade A Steel

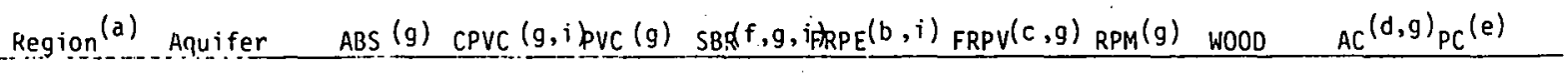

1 Sands tone $\quad 8558$

2 Alluvium $\quad 6124$

$\frac{12007}{.247}$

$\frac{6124}{.158}$

3 Basalt

8119

$\frac{9480}{.244} \quad 14609$

3. Basalt

.179

.376

$4 \quad$ Sandstone

6174

11204

.376
11977
.264

.177

.247

$\frac{.264}{11977}$

$7 \quad$ Sands tone

4890

.120

$\underline{9410} \quad \underline{12227}$

$\frac{.269}{.350}$

$\underline{8110} \quad \underline{10668}$

(a) Numbers refer to Ground Water Regions illustrated in Fig. 5 of Appendix $B$

(b) Fiberglass Reinforced Epoxy Casing

(c) Fiberglass Reinforced Vinylester Casing

(d) Asbestos Cement Casing

(e) Polymer Concrete Casing

(f) Application exceeds maximum temperature limit of casing for both production and injection wells

(g) Application exceeds maximum depth limit of casing

(h) Required diameter is too small for this type of casing

(i) Required diameter is too large for this type of casing 
Results of the cost comparisons are shown in Table 2.16.

4. Educational Institution 30

The Oregon Institute of Technology campus is heated directly by $88^{\circ} \mathrm{C}\left(190^{\circ} \mathrm{F}\right)$ geothermal fluid. It consists of eight buildings covering approximately $51,095 \mathrm{~m}^{2}$ (549, 782 $\mathrm{ft}^{2}$ ) of floor space. Three hot water well is vary in depth from 393 to $549 \mathrm{~m}$ (1288 to $1800 \mathrm{ft}$ ) and in diameter from 356 $\mathrm{mm}(14 \mathrm{in})$ at the top to $203 \mathrm{~mm}(8 \mathrm{in})$ at the bottom with casing varying from $305 \mathrm{~mm}$ to $152 \mathrm{~mm}(12-6$ in) in diameter. These wells can be individually pumped up to $28.4 \mathrm{l} / \mathrm{s}$ (450 gpm). Up to two wells are used at one time. The water is discharged at $52^{\circ} \mathrm{C}\left(126^{\circ} \mathrm{F}\right)$ into a lake. 2.17.

The results of the cost comparisons are listed in Table

\section{Municipal Swimming Pool 30}

This system uses one production well $152 \mathrm{~mm}$ (6 in) in diameter and $75 \mathrm{~m}(246 \mathrm{ft})$ deep to deliver $1.61 / \mathrm{s}(25 \mathrm{gpm})$ of $93^{\circ} \mathrm{C}\left(200^{\circ} \mathrm{F}\right)$ water to heat a large municipal swimming pool. The water is then discharged into the city storm sewer system.

Table 2.18 lists the results of the cost comparisons for this system.

F. Direct Process Heat ing

1. Onion Dehydration 17.

Cost analysis for this application assummed two 203-mm ( 8 in) wells, $610-\mathrm{m}(2000 \mathrm{ft})$ deep delivering a total of $56.8 \mathrm{l} / \mathrm{s}(900 \mathrm{gpm})$ of $110^{\circ} \mathrm{C}\left(230^{\circ} \mathrm{F}\right)$ water, and one $203-\mathrm{mm}(8$ in- $), 305 \mathrm{~m}-(1000 \mathrm{ft}-)$ deep injection well disposing fluid of $77^{\circ} \mathrm{C}\left(171^{\circ} \mathrm{F}\right)$. 2.19.

Results of the cost comparison are presented in Table

\section{Alfalfa Drying 17}

This system uses one production well $203 \mathrm{~mm}$ ( 8 in) in diameter and $457 \mathrm{~m}(1500 \mathrm{ft}$ ) deep and one injection well of the same diameter but $152 \mathrm{~m}(500 \mathrm{ft})$ decp. The production 
Table 2.17

Savings Per Year (1980 Dollars)

Savings/Gigajoule/Year

Application: Heating Educational Institution

Basis of Comparison: API Grade K-55 Steel

Region $^{(a)}$ Aquifer $\quad A B S^{(f, g)} C_{C P V C}\left(g, i p_{V C}(f, g)_{S B R}\left(f, g, F_{R P E}(b, f, i)_{F R P V}(c, f)_{R P M}\left(f, g h_{W O O D} \quad A C(d, g)_{P C}(e)\right.\right.\right.$

$\begin{array}{ccccc}1 & \text { Sandstone } & \frac{2054}{.076} & \frac{3816}{.149} & \frac{13437}{.498} \\ 2 & \text { Alluvium } & \frac{5713}{.258} & \frac{7563}{.360} & \frac{17920}{.809} \\ 3 & \text { Basalt } & \frac{2836}{.110} & \frac{4549}{.185} & \frac{13829}{.534} \\ 4 & \text { Sandstone } & \frac{2146}{.108} & \frac{5478}{.290} & \frac{14149}{.709} \\ 7 & \text { Sandstone } & \frac{936}{040} & \frac{2748}{.125} & \frac{12780}{.580}\end{array}$

(a) Numbers refer to Ground Water Regions illustrated in Fig. 5 of Appendix B

(b) Fiberglass Reinforced Epoxy Casing

(c) Fiberglass Reinforced Vinylester Casing

(d) Asbestos Cement Casing

(e) Polymer Concrete Casing

(f) Application exceeds maximum temperature limit of casing for both production and injection wells

(g) Application exceeds maximum depth limit of casing

(h) Required diameter is too small for this type of casing

(i) Required diameter is too large for this type of casing

Table 2.18

Savings Per Year (1980 Dollars)

Savings/Gigajoule/Year

Application: Swimming Pool Heating

Basis of Comparison: API $5 L$ Grade A Steel

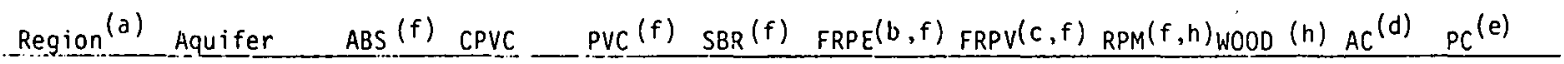

1 Sands tone

$\frac{201}{61}$

$\frac{225}{.68}$

$\frac{517}{1.56} \quad \frac{370}{1.12}$

2 Alluvium

389

$\frac{466}{72}$

$2 \frac{751}{79} \quad 2 \frac{602}{22}$

3 Basalt

412

221

1.30

$\frac{221}{.70}$

$\frac{723}{28} \quad \frac{369}{1.17}$

4 Sandstone

$1 \frac{360}{.47}$

$\frac{209}{.86}$

$2.28 \quad 1.17$

7 Sandstone

$\frac{102}{.36}$

$\frac{152}{.53}$

$2 \frac{679}{2.78} \quad \frac{386}{1.58}$

$\frac{152}{.53}$

$1 \frac{423}{1.49}$

313

(a) Numbers refer to Ground Water Regions lllustrated in Fig. 5 of Appendix B

(b) Fiberglass Reinforced Epoxy Casing

(c) Fiberglass Reinforced Vinylester Casing

d) Asbestos Cement Casing

e) Polymer Concrete Casing

(f) Application exceeds glaximum temperature 11 mit of casing for both production and injection wells

g) Application exceeds maximum depth 1 imit of casing

(h) Required diameter is too small for this type of casing

(i) Required diameter is too large for this type of casing 
Table 2.19

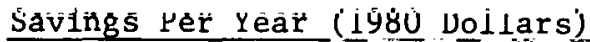

\section{Savings/Gigajoule/Year}

Application: Ünion Uehydration

Basis of Comparison: API Grade K-55 Steel

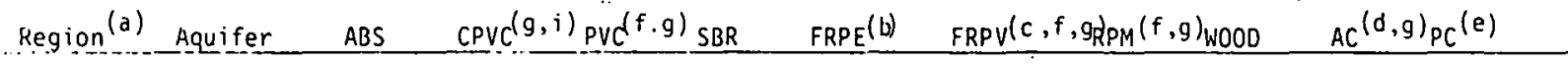

$1 \quad$ Sandstone $\quad \underline{7366}$

$2 \quad$ Alluvium $\quad 8362$

$\frac{8362}{92}$

$\underline{4985}$

.55

$\frac{2571}{.28} \quad \frac{10542}{1.17}$

3 Basalt $\quad 9106$

6154

$3812 \quad 12054$

$\frac{9106}{1.00}$

4 Sandstone 8747

$\underline{7283}$

$-.81$

$\frac{6686}{.74}$

$.42-1.33$

$\frac{4835}{.53}$

11792

$\frac{8747}{.96}$

7 Sandstone $\frac{7688}{.85}$

5381

$\frac{5381}{.63}$

4293

7.30

$\frac{12105}{1.34}$

$\frac{.47}{1.34}$

$2974 \quad 10675$

(a) Numbers refer to Ground Water Regions illustrated in Fig. 5 of Appendix $B$

(b) Fiberglass Reinforced Epoxy Casing

c) Fiberglass Reinforced Vinylester Casing

(d) Asbestos Cement Casing

(e) Polymer Concrete Casing

(f) Application exceeds maximum temperature limit of casing for both production and injection wells

(g) Application exceeds maximum depth limit of casing

(h) Required diameter is too small for this type of casing

(i) Required diameter is too large for this type of casing 
well supplies $18.91 / \mathrm{s}(300 \mathrm{gpm})$ of $104^{\circ} \mathrm{C} .\left(219^{\circ} \mathrm{F}\right)$ fluid to dry $1,452 \mathrm{kgs} / \mathrm{hr}(3200 \mathrm{lb} / \mathrm{hr})$. of alfalfa. Return fluid temperature is $79^{\circ} \mathrm{C}\left(174^{\circ} \mathrm{F}\right)$. 2.20 .

Results of the cost comparisons are summarized in Table

3. Beet Sugar Plant 17

For this system, thirty-two production wells and sixteen injection wells are required. 'Twenty-six production welis are in operation delivering a total of $410 \mathrm{l} / \mathrm{s}(6,500 \mathrm{gpm})$ of $149^{\circ} \mathrm{C}\left(300^{\circ} \mathrm{F}\right)$ fluid. Thirteen injection wells dispose of $102^{\circ} \mathrm{C}\left(216^{\circ} \mathrm{F}\right)$ fluid. The diameter and depth of all wells is $203 \mathrm{~mm}$ ( $8 \mathrm{in})$ and $305 \mathrm{~m}(1000 \mathrm{ft})$ respect ively.

Cost comparison results are listed in Table 2.21 .

4. Salt Evaporation 17

This system assumes five production wells and three injection wells of $203 \mathrm{~mm}$ ( $8 \mathrm{in}$ ) diameter and $305 \mathrm{~m}$ (1000 $\mathrm{ft}$ ) in depth. Four of the production wells supply a total of $63.11 / \mathrm{s}(1,000 \mathrm{gpm})$ of $149^{\circ} \mathrm{C}\left(300^{\circ} \mathrm{F}\right)$ water to flash steam units. Discharge water temperature of $64^{\circ} \mathrm{C}\left(147^{\circ} \mathrm{F}\right)$ is returned to the aquifer through two of the injection wells.

Results of the cost comparisons are shown in Table 2.22.

5. Tomato Paste Plant 17

For this system, twenty-one production wells and eleven injection wells are required. Diameter and depth of the well $\mathrm{s}$ are the same, $203 \mathrm{~mm}(8 \mathrm{in})$ and $305 \mathrm{~m}$ (1000 ft). Seventeen of the production wells are used to supply a total of $268.1 \mathrm{l} / \mathrm{s}(4,250 \mathrm{gpm})$ of $149^{\circ} \mathrm{C}\left(300^{\circ} \mathrm{F}\right)$ fluid to flash steam units. Nine injection wells dispose of $71^{\circ} \mathrm{C}\left(160^{\circ} \mathrm{F}\right)$ fluid.

Table 2.23 lists the results of the cost comparisons of this system. 


\section{Pulp and Paper Plant 34}

This system uses twenty six production wells $203 \mathrm{~mm}(8$ in) in diameter and $1,829 \mathrm{~m}(6000 \mathrm{ft})$ deep del ivering a total of $823 \mathrm{l} / \mathrm{s}(13,043 \mathrm{gpm})$ of $121^{\circ} \mathrm{C}\left(250^{\circ} \mathrm{F}\right)$ water.

Injection wells of the same number and dimension as the production wells dispose of $63.5^{\circ} \mathrm{C}\left(146^{\circ} \mathrm{F}\right)$ brine to a permeab le aquifer.

Table 2.24 lists the cost comparison results. 
Table 2.20

Savings. Per Year (1980 Dollars)

Savings/Gigajoule/Year

Application: Alfalfa Drying

Basis of Comparison: API Grade L-55 Stee 1

Region (a) Aquifer ABS CPVC $(g, i)_{P V C}(f, g)_{S B R}(f, g)_{F R P E}(b, f)_{F R P V}\left(c, f, g_{R P M}(f . g)_{W O O D} \quad A C(d, g) P_{P C}(e)\right.$

$\begin{array}{llllll}1 & \text { Sandstone } & \frac{2997}{.004} & \frac{2000}{.006} & \frac{1044}{.003} & \frac{4212}{.013} \\ 2 & \text { Alluvium } & \frac{4463}{.014} & \frac{3798}{.012} & \frac{2857}{.009} & \frac{6149}{.019} \\ 3 & \text { Basalt } & \frac{2890}{.009} & \frac{1934}{.006} & \frac{950}{.003} & \frac{3727}{.011} \\ 4 & \text { Sandstone } & \frac{3542}{.011} & \frac{2680}{.008} & \frac{1718}{.005} & \frac{4837}{.015} \\ 7 & \text { Sandstone } & \frac{3116}{.010} & \frac{2158}{.007} & \frac{4265}{.013} & \frac{1191}{.004}\end{array}$

(a) Numbers refer to Ground Water Regions illustrated in Fig. 5 of Appendix $B$

(b) Fiberglass Reinforced Epoxy Casing

(c) Fiberglass Reinforced Vinylester Casing

(d) Asbestos Cement Casing

(e) Polymer Concrete Casing

(f) Application exceeds maximum temperature limit of casing for both production and injection wells

(g) Application exceeds maximum depth limit of casing

(h) Required diameter is too small for this type of casing

(i) Required diameter is too large for this type of casing

Table 2.21

Savings Per Year (1980 Dollars)

Savings/Gigajoule/Year

Application: Beet Sugar Plant

Basis of Comparison: API Grade K-55 Steel

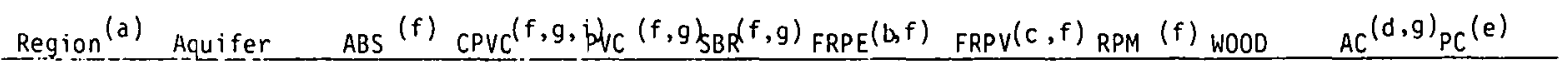

$1 \quad$ Sandstone

2 Alluvium

3 Basalt

$4 \quad$ Sandstone

7 Sandstone $\frac{38405}{.042}$

79846

.088

56339

$\frac{56339}{.062}$

$\underline{51669}$

.057

$\frac{41501}{.046}$
42634

.047

79625

$\frac{79625}{.088}$

55201

$\frac{55201}{.061}$

55147

.067

$\underline{44286}$

.049 $\frac{82222}{.091}$

$\frac{120016}{132}$

91971.

.101

94414

.704

$\frac{83264}{092}$

(a) Numbers refer to Ground Water Regions illustrated in Fig. 5 of Appendix $B$

(b) Fiberglass Reinforced Epoxy Casing

(c) Fiberglass Reinforced Vinylester Casing

(d) Asbestos Cement Casing

(e) Polymer Concrete Casing

(f) Application exceeds maximum temperature 1 imit of casing for both production and injection wells

g) Application exceeds maximum depth limit of casing

(h) Required diameter is too small for this type of casing

(i) Required diameter is too large for this typc of casing 
Table 2.22

Savings Per. Year (1980 Dollars)

Savings/Gigajoule/Year

Application: Salt Evaporation

Basis of Comparison: API Grade K-55 Steel

\begin{tabular}{|c|c|c|c|c|c|c|c|c|}
\hline Region (a) & Aquifer & $A B S$ & $C P V C^{(g)} P V C^{(g)}$ & $S B R^{(f, g)} F R P E(b)$ & FRPV $(c)$ & RPM & WOOD & $A C^{(d, g)} P C^{(e)}$ \\
\hline 1 & Sandstone & $\frac{12283}{.033}$ & & $\begin{array}{l}7879 \\
.021\end{array}$ & $\begin{array}{l}.8657 \\
.023\end{array}$ & $\begin{array}{r}10430 \\
.028\end{array}$ & $\begin{array}{l}8458 \\
.011\end{array}$ & $\begin{array}{r}13232 \\
.036\end{array}$ \\
\hline 2. & Alluvium & $\frac{18684}{.051}$ & & $\begin{array}{l}13577 \\
.037\end{array}$ & $\frac{15016}{.041}$ & $\begin{array}{r}16874 \\
.048\end{array}$ & $\frac{14859}{.040}$ & $\begin{array}{r}23622 \\
.064\end{array}$ \\
\hline 3 & Basalt & $\frac{14866}{.040}$ & & $\begin{array}{l}11556 \\
.029^{\circ}\end{array}$ & $\begin{array}{r}11355 \\
.030\end{array}$ & $\begin{array}{r}12978 \\
.035\end{array}$ & $\begin{array}{r}11096 \\
.030\end{array}$ & $\begin{array}{r}1.528 .3 \\
.047\end{array}$ \\
\hline 1 & Sandetone & $\frac{11851}{.040}$ & & $\begin{array}{l}105999 \\
.031\end{array}$ & $\begin{array}{r}11240 \\
\hdashline .031\end{array}$ & $\frac{12396}{.035}$ & $\frac{11032}{.030}$ & $\begin{array}{r}19367 \\
.052\end{array}$ \\
\hline 7 & Sandstone & $\frac{12636}{.034}$ & & $\begin{array}{c}8513 \\
.023\end{array}$ & $\begin{array}{l}3028 \\
.024\end{array}$ & $\begin{array}{l}8498 \\
.0233\end{array}$ & $\begin{array}{l}8715 \\
.0244\end{array}$ & $\begin{array}{r}17079 \\
.046\end{array}$ \\
\hline
\end{tabular}

(a) Numbers refer to Ground Water Regions illustrated in Fig. 5 of Appendix B

(b) Fiberglass Reinforced Epoxy Casing

(c) Fiberglass Reinforced Vinylester Casing

(d) Asbestos Cement Casing

(e) Polymer Concrete Casing

(f) Application exceeds maximum temperature limit of casing for both production and injection wells

(g) Application exceeds maximum depth limit of casing

(h) Required diameter is too small for this type of casing

(i) Required diameter is too large for this type of casing

Table 2.23

Savings Per Year (1980 Dollars)

Lavings/Cigajoule/Year

Application: Tomato Paste Plant

Basis of Comparison: API Grade K-55 Steel

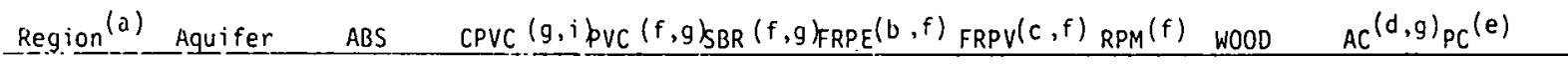

\begin{tabular}{|c|c|c|c|c|c|}
\hline 1 & sanndstone & $\begin{array}{r}48718 \\
.103\end{array}$ & $\begin{array}{r}31513 \\
.066\end{array}$ & $\frac{34695}{.073}$ & $\frac{5222}{.111}$ \\
\hline$?$ & Al luvium & $\begin{array}{r}74101 \\
.158\end{array}$ & $\frac{51353}{.114}$ & $\frac{60952}{.128}$ & $\begin{array}{r}94436 \\
.1996\end{array}$ \\
\hline 3 & Basalt & $\frac{58959}{.124}$ & $\frac{52534}{.111}$ & $\frac{45516}{.096}$ & $\begin{array}{r}67437 \\
.142\end{array}$ \\
\hline 4 & Sandstone & $\begin{array}{r}68899 \\
.724\end{array}$ & $\begin{array}{r}4.2 .89 \\
.089\end{array}$ & $\frac{45.85 .7}{.095}$ & $\begin{array}{r}77469 \\
.163\end{array}$ \\
\hline 7 & Sands tone & $\frac{50114}{.106}$ & $\frac{34053}{.072}$ & $\frac{35749}{.075}$ & $\frac{68317}{.144}$ \\
\hline
\end{tabular}

(a) Numbers refer to Ground Water Regions illustrated in Fig. 5 of Appendix 8

(b) Fiberglass Reinforced Epoxy Casing

(c) Fiberglass Reinforced Vinylester Casing

(d) Asbestos Cement Casing

(e) Polymer Concrete Casing

(f) Application exceeds maximum temperature limit of casing for both production and injection wells

(g) Application exceeds maximum depth limit of casing

(h) Required diameter is too small for this type of casing

(i) Required diameter is too large for this type of casing 
Table 2.24

Savings Per Year (1980 Dollars)

Savings/Gigajoule/Year

Application: Pulp and Paper Plant

Basis of Comparison: API Grade K-55 Steel

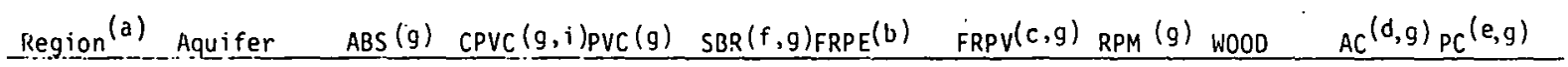

1

Sands tone

$\frac{1228600}{5.27}$

$\frac{1220900}{5.24}$

$2 \quad$ Sands tone

1228600

1220900

3 Sandstone

5.27

5.24

1228600

5.27

1220900

4 - Sandstone

$\frac{1228600}{5.27}$

5.24

1220900

(a) Numbers refer to Ground Water Regions illustrated in Fig. 5 of Appendix $B$

(b) Fiberglass Reinforced Epoxy Casing

(c) Fiberglass Reinforced Vinylester Casing

(d) Asbestos Cement Casing

(e) Polymer Concrete Casing

(f) Application exceeds maximum temperature limit of casing for both production and injection wells

(g) Application exceeds maximum depth limit of casing

(h) Required diameter is too small for this type of casing

(i) Required diameter is too large for this type of casing 


\section{ECONOMIC IMPACT}

A. Savings Due to Nonmetallic Wells

The economic impact of using nonmetallic materials in low-temperature geothermal well construction depends on the extent to which low-temperature geothermal resources are used. The Department of Energy/Division of Geothermal Energy nonelectric geothermal development scenario was used to calculate thermal power on-line from the years 1981 to 2013 for residential/commercial, industrial, and agricultural applications in four western regions and one eastern region. 35 The data for the eastern region was not used in the present study since its excess ive well depllis prohibit use of nonmetallic casing. Thermal power data for the remaining four regions were combined with dat.a nn savings per gigajoule from the cost comparisons to arrive at annual savings for the three use categories in the four regions. Fiberglass reinforced epoxy was selected as the nonmetallic casing material for all applications in the four regions due to its high strength and temperature resistance. Average savings per gigajoule were used based on the savings resulting from the use of fiberglass reinforced epoxy in actual geothermal systems in each region. The savings were inflated at a 12 percent compound rate and cumulated over the 33 years to arrive at a total savings. The results of these calculations are shown in Table 3.1 and Figure 3.1.

TARLE 3.1

Total Savings From 1981-2013 Due To The Use of Fiberglass Reinforced Epoxy Materials In Wells For Nonelectric Geothermal Systems

\begin{tabular}{lrrr} 
& \multicolumn{3}{c}{$\left(10^{6}\right.$ dollars $)$} \\
Region & $\begin{array}{l}\text { Residential } \\
\& \text { Commercial }\end{array}$ & Industrial & Agricultural \\
$\begin{array}{l}\text { Western Mt. } \\
\text { Range }\end{array}$ & 331.22 & 85.36 & 8.24 \\
$\begin{array}{l}\text { Alluvial Basins } \\
\text { Columbia Lava }\end{array}$ & 680.41 & 303.21 & 60.52 \\
$\begin{array}{l}\text { PTateau } \\
\text { Unglaciated }\end{array}$ & 387.65 & 394.63 & 1.46 \\
Central Region & 218.06 & 149.0678 & 0.78 \\
Total U.S. & $1,617.34$ & 932.27 & 71.00
\end{tabular}




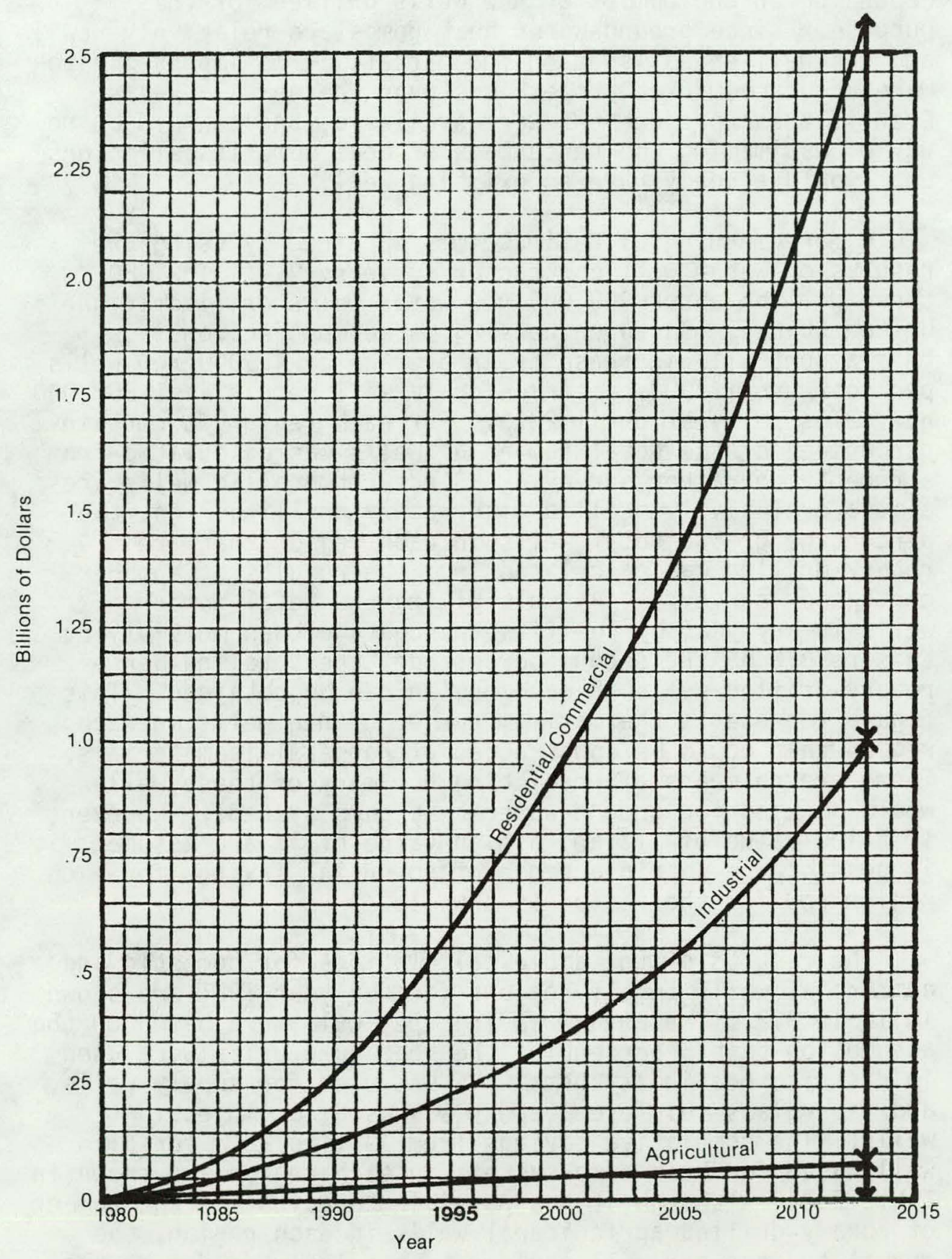

Figure 3.1. Cumulative Savings Resulting. From the Use of Fiberglass Reinforced Epoxy We11 Casing for Low-Temperature Geothermal Systems 
The use of nonmetallic materials in wells for groundwater heat pump systems can result in considerable savings depending on the number of new wells drilled for this purpose. Since ground-water heat pumps are relatively new and not well-established on the market, it is impossible to make accurate market projections over the next 33 years. Even if these projections were available, there would be no way of estimating the percentage of heat pump installations that would al ready have an existing well.

A more meaningful estimate was obtained by using the results of water well contractor surveys. 36,37 In 1980 there will be about 900,000 new water wells drilled in the United States. Based on housing market. projections ${ }^{38}$, this amount will increase by an average of 45,000 ncw wclls per year unt il 1990, after which it will remain at 1,350,000 now wells per year until 2013, For each region, a certain percentage of the total number of wells was calculdaled rrum a recent contractor survey. 36 since nonmetallic wells are almost exclusively drilled with rotary drilling rigs, the percentage of the total wells in each region that are rotary-drilled was calculated from the results of another contractor survey. 37 By multiplying the total number of wells in any year by the first percentage then multiplying this result by the second percentage, the total number of rotary-drilled wells in each region can be obtained. This figure represents the maximum number of new wells in each region that could be constructed of nonmetallic materials. There are no means of predicting how many of these wells would be used for ground-water heat pump systems. However, if a low value of . $1 \%$ and a high value of $1 \%$ are assumed, it is possible to obtain a range of potential savings for each region and for the nation as a whole.

The results of the above calculations for domestic and commercial wells in all regions for the year 1981 are shown in Table 3.2. The annual savings per well were based on the assumption that 5 percent of the heat pump units were used in district heating systems, PVC was used for supply wells, and fiberglass reinforced epoxy was used for injection wells. The cumulative savings from 1981 to 2013 for all wells used for heat. pump systems in each region are shown in Table 3.3. Although it was possible to calculate the number of rotary-drilled agricultural wells in each region, the annual savings per well could not be calculated due to the absence of data on actual agricultural heat pump systems. 
Table 3.2

Annual Savings Resulting From the Use of Nonmetallic Materials in Wells for Domestic and Commercial Heat Pump Systems (1981)

\begin{tabular}{|c|c|c|c|c|c|c|c|c|c|c|c|}
\hline \multirow[t]{2}{*}{ * Region } & $\begin{array}{r}\% \\
\text { of Tutal } \\
\text { New WeIls } \\
\end{array}$ & $\begin{array}{c}\text { No. of } \\
\text { New Wells }\end{array}$ & $\begin{array}{c}\% \\
\text { Rotary-Drilled } \\
\text { Domestic/Commercial }\end{array}$ & \multicolumn{2}{|c|}{$\begin{array}{c}\text { No. } \\
\text { Rotary-Drilled } \\
\text { Domestic/Commercial }\end{array}$} & $\begin{array}{l}\text { No. Heat } \\
\text { Pump Wells } \\
\text { Assuming. } 1 \%\end{array}$ & $\begin{array}{l}\text { Annual } \\
\text { Savings } \\
\text { Per Well }\end{array}$ & $\begin{array}{l}\text { Total } \\
\text { Annual } \\
\text { Savings } \\
\end{array}$ & $\begin{array}{l}\text { No. Heat } \\
\text { Pump Wells } \\
\text { Assuming }\end{array}$ & \multicolumn{2}{|c|}{ 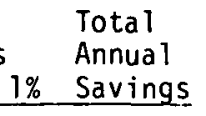 } \\
\hline & & & & & & & . & & & & \\
\hline 1 & 3.629 & 34,294 & 23.06 & 7,908 & & 8 & $\$ 394$ & $\$ 3,151$ & 79. & & $\$ 31,112$ \\
\hline 2 & 4.607 & 43,536 & 23.02 & 10,022 & & 10 & 592 & 5,924 & 100 & & 59,238 \\
\hline 3 & 1.264 & 11,945 & 23.135 & 2,752 & & 3 & 343 & 1,029 & 28 & & 9,607 \\
\hline 4 & 1.0335 & 9,767 & 22.78 & 2,225 & & 2 & 335 & 670 & 22 & & 7,376 \\
\hline 5 & 5.306 & 50,142 & 41.89 & 21,004 & & 21 & 566 & 11,883 & 210 & & 118,833 \\
\hline 6 & 31.2405 & 295,223 & 29.61 & 87,416 & & .87 & 820 & 71,360 & 874 & & 716,883 \\
\hline 7 & 15.59 & $-47,325$ & 35.95 & 52,963 & & 53 & 297 & 15,727 & 530 & & 157,268 \\
\hline 8 & 10.469 & 98,932 & 27.612 & 27,317 & & 27 & 285 & 7,698 & 273 & & 77,834 \\
\hline 9 & 10.65 & 00,643 & 7.602 & 7,650 & & 8 & 618 & 4,942 & 77 & & 47,568 \\
\hline 10 & 16.211 & 153,194 & 41.412 & 63,441 & - & 63 & 529 & 33,323 & 634 & & 335,342 \\
\hline TOTAL & .5. & $\$ 45,000$ & . & 282,698 & . & 283 & & $\$ 155,707$ & $\because, 827$ & & $1,561,062$ \\
\hline $\begin{array}{l}\text { TOTAL } \\
\text { FOR U. }\end{array}$ & $\begin{array}{l}\text { NNUAL SAVI } \\
\text {. ASSUMIHG }\end{array}$ & $.1: 5155$ & 707 & & & & & & & & \\
\hline $\begin{array}{l}\text { TOTAL } \\
\text { FOR U. }\end{array}$ & $\begin{array}{l}\text { NNUAL SAYIA } \\
\text {. ASSUMING }\end{array}$ & $\begin{array}{l}\text { GS } \\
1 .: \text { S1,5 }\end{array}$ & .062 & & & & & & & & \\
\hline
\end{tabular}

* Numbers refer to Ground Water Regions : llustrated in Fig. 5 of Appendix B 
TABLE 3.3

Cumulative Savings From 1981-2013 Due To The Use of Nonmetallic Materials In Wells . For Heat Pump Systems $\left(10^{6}\right.$ dollars)

\begin{tabular}{|c|c|c|}
\hline Region & Residential \& Commercial & Industria \\
\hline $\begin{array}{l}\text { Western Mt.. } \\
\text { Ranges }\end{array}$ & $\begin{array}{l}238.46 * \\
? 3.85 \approx \pi\end{array}$ & $\begin{array}{r}\$ 12.33 \\
1.23\end{array}$ \\
\hline $\begin{array}{l}\text { Alluvial } \\
\text { Basins }\end{array}$ & $\begin{array}{r}472.57 \\
47.26\end{array}$ & $\begin{array}{r}15.62 \\
1.56\end{array}$ \\
\hline $\begin{array}{l}\text { Columbia Lava } \\
\text { Plateau }\end{array}$ & $\begin{array}{r}69.87 \\
6.99\end{array}$ & $\begin{array}{r}4.31 \\
.43\end{array}$ \\
\hline $\begin{array}{l}\text { Colorado } \\
\text { Plateau }\end{array}$ & $\begin{array}{r}56.01 \\
5.60\end{array}$ & $\begin{array}{r}3.47 \\
.35\end{array}$ \\
\hline High Plains & $\begin{array}{r}945.06 \\
9.45\end{array}$ & $\begin{array}{r}32.75 \\
3.28\end{array}$ \\
\hline $\begin{array}{l}\text { Glaciated } \\
\text { Central Reyiun }\end{array}$ & $\begin{array}{r}5,700.88 \\
570.09\end{array}$ & $\begin{array}{r}136.34 \\
13.63\end{array}$ \\
\hline $\begin{array}{l}\text { Unglaciated } \\
\text { rentral Region }\end{array}$ & $\begin{array}{r}1,159.11 \\
115.91\end{array}$ & $\begin{array}{r}82.59 \\
8.26\end{array}$ \\
\hline $\begin{array}{l}\text { Unglaciated } \\
\text { Appalachians }\end{array}$ & $\begin{array}{r}564.69 \\
56.47\end{array}$ & $\begin{array}{r}42.59 \\
4.26\end{array}$ \\
\hline $\begin{array}{l}\text { Glaciated } \\
\text { Appalachians }\end{array}$ & $\begin{array}{r}142.82 \\
14.28\end{array}$ & $\begin{array}{r}4.52 \\
.15\end{array}$ \\
\hline Coastal Plain & $\begin{array}{r}2,627.40 \\
762.74\end{array}$ & $\begin{array}{r}98.92 \\
9.90\end{array}$ \\
\hline Total U.S. & $\begin{array}{r}\$ 11,976.87 \\
1,19 \% .69\end{array}$ & $\begin{array}{r}\$ 433.44 \\
43.34\end{array}$ \\
\hline
\end{tabular}




\section{B. Savings in Energy Consumption During Manufacturing}

Any economic comparison between metallic and nonmetallic materials would be incomplete without considering the amount of energy required to manufacture a product. Steel manufacturing is more energy intensive than the manufacturing of plastics and other nonmetallics due primarily to the lighter weight of most nonmetallic products. and secondarily to lower process heating requirements for the manufacture of some nonmetallic products. In the case of plastics, part of the energy is in the resin itself and is, for all practical purposes, used up. Thus, for a metric ton of plastic resin, approximately $44.74 \mathrm{GJ}$ (42.41 million BTU) are used compared with 39.55 GJ (37.49 million BTU) for a ton of steel. During pipe manufacturing, an additional 97.70 GJ (92.61 million BTU) for plastic and 54.20 GJ (51.41 million BTU) for steel are required for each ton. However, in the final analysis, approximately four times as much energy is required to manufacture steel pipe than plastic pipe due to its greater weight.

By using an average well casing length per gigajoule in the geothermal systems in the western regions and an average casing length per well in the heat pump systems, a total length of $1.4127 \times 10^{7}$ meters of casing will be required from 1981 to 2013. The weight of this amount of casing is 75643.5 tons and 481327 tons for plastic and steel, respectively. The energy required to manufacture this casing is $10,774,600 \mathrm{GJ}$ for plastic and 45,12.4,406 GJ for steel. Thus, the energy saved in manufacturing plastic casing is $34,349,806$ GJ or the equivalent of 5.87 million barrels of oil. 
NOTES ON UNITS

The geothermal community is an international one, thus all units are given in the International System (SI) with English (Engineering) in parenthesis, i.e. $160^{\circ} \mathrm{C}\left(140^{\circ} \mathrm{F}\right)$. Every attempt was made to use the same number of significant figures in both systems. Thus, for example, $150^{\circ} \mathrm{C}$ would be converted to $302^{\circ} \mathrm{F}$ when used as an exact number (three significant figures), and to $300^{\circ} \mathrm{F}$ when used as an approxinate number (two significant figures).

The following English and International (SI) relationships and abbreviations were used:

\section{English Engineering}

1. poum mass (1h)

1 foot-pound per inch (ft-lb/in)

1 ton (short $=2,000 \mathrm{lb})(\mathrm{tn})$

1 ounce (oz)

1 pound per square foot (psf)

1 pound per square inch (psi)

1 pound per cubic inch (pci)

1 mile (mi)

1 foot $(\mathrm{ft})$

1 inch (in)

1 gallon (gal)

1 gallon per minute (gpm)

1 ton per hour ( $T / \mathrm{hr})$

1 British themal unit (BTU)

British thermal unit per hour (BTU/hr) 1 acre (A)

${ }^{\star} 1$ degree Fahremeit $\left({ }^{\circ} \mathrm{F}\right)$

$1^{\circ} \mathrm{F} / \mathrm{mile}$
International System (SI)

$=0.4536$ kiloqrams $(\mathrm{kq})$

$=0.054$ kilogram-meters per cent imeter $(\mathrm{kg}-\mathrm{m} / \mathrm{am})$

$=0.3072$ tonne (metric $=1,000 \mathrm{~kg})(\mathrm{t})$

$=28.35$ grams $(\mathrm{g})$

$=4.882 \mathrm{kilograns}$ per square meter $\left(\mathrm{kg} / \mathrm{m}^{2}\right)$

$=0.0703 \mathrm{kilograms}$ per square cent imeter $\left(\mathrm{kg} / \mathrm{cm}^{2}\right)$

$=0.00277 \mathrm{kilograms}$ per clbic cent imeter $\left(\mathrm{kg} / \mathrm{or}^{3}\right)$

$=1.609 \mathrm{kilameter}(\mathrm{km})$

$=0.3048$ meters $(\mathrm{m})$

$=2.540$ cent imeters $(\mathrm{cm})$

$=3.785$ liters ( 1 )

$=0.06308$ liter per second $(1 / \mathrm{s})$

$=.252 \mathrm{kilograms}$ per second $(\mathrm{kg} / \mathrm{s})$

$=1055$ Joules $(\mathrm{J})$

$=1.055$ kilo Joules $(\mathrm{kJ})$

$=0.2930$ watts $(\mathrm{w})$

$=0.4047$ hectares (ha)

$=4047$ square meters $\left(\mathrm{m}^{2}\right)$

$=1.8\left[\right.$ degree celcius $\left.\left({ }^{\circ} \mathrm{C}\right)\right]+32^{\circ}$

$=0.345^{\circ} \mathrm{C} / \mathrm{km}$

1 British thermal unit per hour per foot per degree Fahremeit (BTU/hr.Ft. ${ }^{\circ} \mathrm{F}$ )

$=0.0172958$ Joules per second per cent imeter per degree celcius $\left(\mathrm{J} / \mathrm{s} . \mathrm{cm} .{ }^{\circ} \mathrm{C}\right)$

$$
\begin{aligned}
& 10^{-6}=\text { micro }(\mathrm{u}) \\
& 10^{-3}=\text { milli }(\mathrm{m}) \\
& 10^{-2}=\text { cent } \mathrm{(c}(\mathrm{c}) \\
& 10^{3}=\text { kilo }(\mathrm{k}) \\
& 10^{6}=\operatorname{mega}(\mathrm{M}) \\
& 10^{9}=\text { giga }(\mathrm{G})
\end{aligned}
$$

*If only a change in temperature is required, then $F^{\circ}=1.8 \times\left(\Delta C^{\circ}\right)$ 


\section{REFERENCES}

1. Davis, R. B. and Z. A. Munir: "Corrosion

Susceptibilities of Various Metals and Alloys in Synthetic Geothermal Brines." Journal of Materials Science, Vol. 12 (1977), pp. 1909-1913.

2. Niess, R.C.: "Utilization of Geothermal Energy with an Emphasis on Heat Pumps." In A Symposium of Geothermal Energy and Its Direct Uses in the United States, Geothermal Resources Council, Davis, Cal., April 1979, pp. 73-80.

3. DeBerry, D. W., P. F. El.li.s, and C. C. Thomas:

Materials Selection Guidelines for Geothermal Power Systems. 3rd Ed., Radian Corporation, Report No. AL0-3904-1, 1979.

4. Zeldin, A., L.E. Kukacka, and N. Carciello: "Polymer Systems in Geothermal Applications." Journal of Applied Polymer Science Vol. 23 (1979), pp. 3179-3191.

5. Lorensen, L. E., C. M. Walkup, and C. 0. Pruneda: Polymeric and Composite Materials For Use In Systems Utilizing Hot, Flowing Geothermal Brine III. Lawrence Livermore Laboratory, 1979.

6. Finnegan, S.A.: Coso Geothermal Corrosion Studies. Naval Weapons Center, China Lake, California, 1977.

7. Wright, C.C.: "Corrosion Control in Large Volume Pumping Brine Wells." Materials Protection and Performance Vol. 11, No. 1, pp. 23-26, 1972.

8. George, P. F., J. A. Manning, Jr., and C. F. Schrieber: Desalination Matcrials Manual, Dow Chemical Counpdry, 1975.

9. ASTM Task Group on Geothermal Seals, "Proceedings of Technical Seminar." Conf. 7806141, 1978.

10. National Water Well Association and the Plastic Pipe Institute: Mariudl of Installation Practices for Thermoplastic Water Well Casing, publication date pending approval by ASTM $\Gamma .480$ committee. 
11. Hudson, P. E., and F. W. Nobles: Corrosion Resistant, Nonmetall ic Water Well Systems. Radian Corp., 1973.

12. Taylor, G. A.: Managerial and Engineering Economic Decision-Making, D. Van Nostrand Co., Inc., 1964.

13. Dillon, C. P.: "Economic Evaluation of Corrosion Control Measures." Materials Protection Vol. 4 (1965), No. 5 , pp. 38-45.

14. Jelen, F. C.: Cost and Optimization Engineering. McGraw Hill Book Co., 1970.

15. Yamartinu, J. K.: Installed Cost of CorrosionResistant Piping. Dow Chemical Company, 1977.

16. Nanen, L. W., F. Kreith, and R. E. West: "An Investigation of the Technical and Economical Feasibility of Using Low Temperature Geothermal Sources in Colorado." Energy Vol. 1, pp. 176-216.

17. Bakewell, C. A., N. Book, and E. Hinter Herron: A Geothermal Direct Use Economic and Engineering Study Integration. Gruy Federal, Inc., Aug., 1979.

18. Milora, S. L., and J. W. Tester: Geothermal Energy as a Source of Electric Power. The MIT press, 1976.

19. National Water Well Association: Survey of Water Well Drilling Costs in the United States. Performed for Oak Ridge National Laboratory. In progress.

20. Lammers, J. R.: Private Communication, Burgess Wel.1 Company, Inc. Minden, Nebraska, 1979.

21. Clarice, F. E. and I. Barnes: Evaluation and Control of Corrosion and Encrustation In Tube Wells of the Indus Plains, West Pakistan. U.S.G.S. Water Supply Paper 1608-L. U.S. Governirient Print iny Office, 1909.

22. National Water Well Association: Well Maintenance and Rehabilitation Manual. In progress.

23. Bloomster, C. H.: "An Economic Model For Geothermal Cost Analysis." In Proceedings-Second U.N. Conference on the Development and Use of Geothermal Resources Vol. $3(1975)$, pp. 2275-2281. 
24. Shannon, Donald: Private Communication, EG\&G, Idaho, Inc. Idaho Falls, Idaho, 1979.

25. Culver, G., and G. M. Reistad: Evaluation and Design of Downhole Heat Exchangers for Direct Applications.

Oregon Institute of Technology, 1976.

26. "Cont inued High Activity Escalates Drilling Costs." World 0 il Vol. 188, No. 3, pp. 99-100, February 15, 1979.

27. Chappel1, R. N., S. J. Prestwich, L. G. Miller, and H. P. Ross: "Geothermal Well Drilling Estimates Based on Past Wel1 Costs" Geothermal Resources Council, Transactions, Vo1. 3, Sept., 1979, pp. 99-102.

28. National Water Well Association: A Comprehensive Examination of the Energy Requirements and Costs, With the Environmental and Legal Implications of Expanded Use of Ground Water Geothermal Heat Pumps. In progress.

29. Schaetzle, W. J., and C. E. Brett: Heat Pump-Centered Integrated Community Energy Systems. Univ. of Alabama, 1979.

30. "Multipurpose Use of Geothermal Energy." In Proceedings of the International Conference on Geothermal Energy for Industrial, Agricultural, and Commercial-Residential Uses. Geo-Heat Utilization Center, 1974.

31. Rybach, L.: "Urban Heating from Geothermal Aquifers in the Paris Basin." In A Symposium of Geothermal Energy and Its. Direct Uses in the United States Geothermal Resources CounciT, Davis, Cal., April 1979, pp. 55-58.

32. Angles, P. J.: "Fiberglass Casing Used in Corrosive Geothermal Wells." 0 il and Gas Journal Vol. 77, No. 42, pp. 131-132, Oct. 15, 1979 .

33. Higbee, C. V.: The Economics of Direct Use Geothermal Energy for Process and Space Heating. Geo-Heat Utilization Centers, Oregon Institute of Technology, K.1amoth Falls, Oregon; 1978.

34. "Direct Utilization of Geothermal Energy: A Symposium." Geothermal Resources Council, 1978. 
35. Jacobsen, W. E., and F. W. Williams: Geothermal Nonelectric Development-Anayls is and Summary. The MITR CORP./METREK DIVISION, Maclean, Va., 1977.

36. "Survey of Contractors." Ground Water Age, VoT. 12, No. 2, p 24-26, Oct. 1977.

37. Water Well Contractors Survey. Water Supply Management, 1970.

38. The Kiplinger Washingt on Newsletter, Vol. 57, No. 4, p. 1. Jan. 25, 1980 .

U.S. GOVERNMENT PHIN IING ÜFICE: $614=090-\$ 19$ 